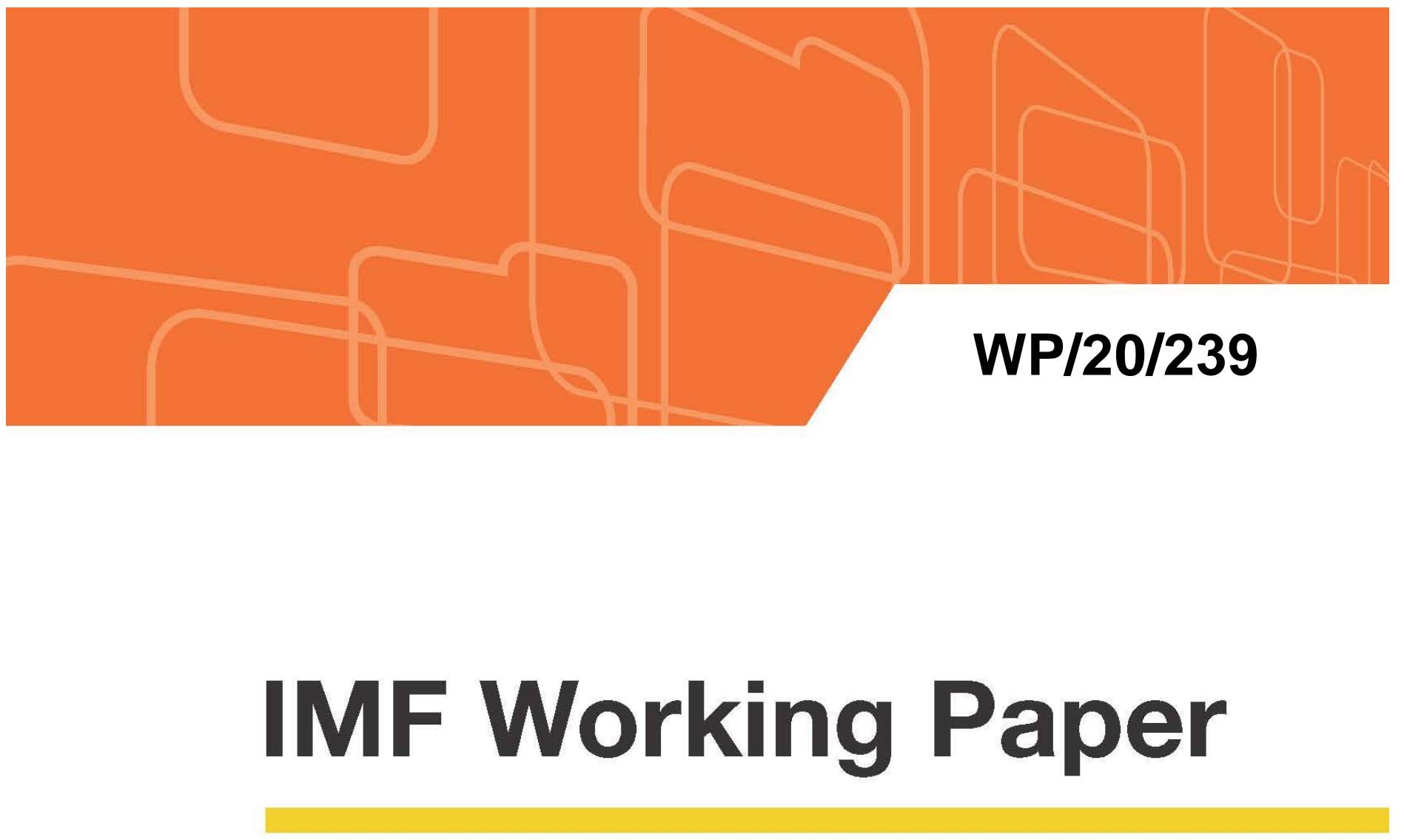

\title{
China's Rebalancing: Opportunities and Challenges for LAC Exporters
}

\author{
by Nitya Aasaavari, Fabio Di Vittorio, Ana Lariau, \\ Yuebo Li, Rui Mano and Pedro Rodriguez
}

IMF Working Papers describe research in progress by the author(s) and are published to elicit comments and to encourage debate. The views expressed in IMF Working Papers are those of the author(s) and do not necessarily represent the views of the IMF, its Executive Board, or IMF management.

Disclaimer: This document was prepared before COVID-19 became a global pandemic and resulted in unprecedented economic strains. It, therefore, does not reflect the implications of these developments and related policies. We direct you to IMF Covid-19 page that includes staff recommendations with regard to the COVID-19 global outbreak. 


\title{
IMF Working Paper
}

Western Hemisphere Department

\author{
China's Rebalancing: Opportunities and Challenges for LAC Exporters \\ Prepared by Nitya Aasaavari, Fabio Di Vittorio, Ana Lariau, Yuebo Li, Rui C. Mano \\ and Pedro Rodriguez
}

Authorized for distribution by Krishna Srinivasan

November 2020

\begin{abstract}
IMF Working Papers describe research in progress by the author(s) and are published to elicit comments and to encourage debate. The views expressed in IMF Working Papers are those of the author(s) and do not necessarily represent the views of the IMF, its Executive Board, or IMF management.
\end{abstract}

\begin{abstract}
Asia and Latin America and the Caribbean (LAC), two regions with large growth potential, have become increasingly connected over the last 20 years. China has emerged not only as a top trading partner, but also as an important competitor of LAC exports. China's retreat from certain markets, due to the ongoing rebalancing process, could open new opportunities for LAC exporters but also entail some challenges. Our results show that China's rebalancing will have an overall positive effect on LAC's GDP and exports in the long run, but this effect is small and uneven across countries, leading to winners and losers. We also provide evidence that other countries, such as India, are currently trying to fill the gap left by China and could undermine LAC's competitive advantage in some export markets. In this context, reduction of trade barriers and further integration within the region and/or with the rest of the world would lead to unequivocally positive outcomes for all LAC countries. The COVID-19 shock might exacerbate the effects identified in our analysis.
\end{abstract}

JEL Classification Numbers: F12, F14, F15, F43

Keywords: China's rebalancing, Latin America and the Caribbean, trade integration

Author's E-Mail Address: nitya.aasaavari@gmail.com; fdivittorio@imf.org; alariaubolentini@imf.org; yli6@imf.org; rmano@imf.org; prodriguez@imf.org 


\section{INTRODUCTION}

Globalization and economic integration create both opportunities and challenges. Enhancing trade between regions by removing the impediments to deeper integration provides new opportunities to boost regional growth and promote risk-sharing. However, higher interdependence could also be a source of vulnerabilities, since shocks could propagate directly or indirectly across countries. Studying interlinkages between regions has become crucial to understand both the drivers and the bottlenecks of global growth, and de sign adequate economic policies.

Asia and LAC have become increasingly connected over the last 20 years, particularly through international trade. The expansion of LAC's trade with Asia has been primarily driven by the emergence of China both as the main export destination for commodities and source of manufactured imports. Section II of this paper documents key stylized facts about Asia-LAC trade linkages, their magnitude, and the main countries and sectors connecting the two regions.

The progressive shift of China from an investment- to a consumption-led economy poses new challenges for LAC countries. The deceleration of China's demand for commodities may have implications for LAC exporters. While the demand for food products may remain high to support a growing urban population in China (Casanova et al, 2016), the demand for mineral intermediate inputs may decline over time. Such development could have severe repercussions on some LAC economies, such as the countries in the Andean region; this is the case of Chile, due to its high export dependence on China in the minerals market. Also, the shift in the product composition of Chinese demand will continue to affect the evolution of commodity prices; as the growth in the demand for products moderates, it might lead to further declines in food prices.

We analyze this phenomenon through the lenses of a multi-sector computable general equilibrium trade model. The results, reported in Section III, show that China's rebalancing will have an overall positive effect on LAC's GDP and exports in the long run. However, the magnitude of the impact will be small on average and uneven across countries, leading to winners and losers. The long-run outcome will depend on the countries' ability to shift their production structures towards (i) sectors that meet the Chinese demand for new products, or (ii) sectors from which China is retreating. Countries with a high initial dependence on minerals production will fare comparatively worse, seeing larger employment displacement and a greater share of their economies affected due to second round effects of reduced demand and input-output linkages. At the same time, as China shifts towards a greater production of services to respond to increased demand there, LAC exports of services in many countries would decline due to the increased competition.

These findings support the idea that China's rebalancing opens a window of opportunity and that LAC has the potential to benefit from this structural transformation in the long run. However, would the current competitive landscape of LAC exports allow for it? Are there other emerging competitors that might also fight for that space in the short and medium run? In Section IV we provide evidence that, in recent years, other countries, such as India, have 
been trying to fill the gap left by China. This could undermine LAC's competitive advantage in certain export markets in the upcoming years and limit any potential benefits from China's rebalancing.

What can LAC do to reap the benefits from China's structural transformation? Based on the model developed in Section II, we find that a reduction of trade barriers and further integration within the region and/or with the rest of the world would lead to unequivocally positive outcomes for all LAC countries. The results of this exercise are reported in Section V. Other reforms, such as reducing trade costs and improving the quality of the exported products, would also ensure that the region remains competitive.

Section VI discusses how the COVID-19 outbreak might affect these trends. While any prediction remains speculative at this point, given the high degree of uncertainty surrounding the pandemic, we hypothesize that COVID-19 will exacerbate the effects identified in our analysis. We argue that countries that were already expected to benefit from China's rebalancing, will likely do even better. And those countries that were set to lose, will do even worse. The pandemic will amplify the gap between winners and losers from China's rebalancing. There are at least two channels through which this might happen: (i) regionalization and diversification of global value chains; and (ii) decline in services involving a high degree of person-to-person interaction.

\section{ASIA-LAC TRADE LINKAGES AND THE EMERGENCE OF CHINA}

As noted by Kahn et al (2012), trade between Asia and LAC started to gain relevance after World War II and has been shaped by three waves. The first one is associated with the rise of Japan, which became a buyer of natural resources for the region, as well as a source of investment and industrial goods. The second wave corresponds to the rise of the Asian tigers-Hong Kong SAR, South Korea, Singapore and Taiwan Province of China-in the 1970-80s. The third (and ongoing) wave, which started in the early 2000s, relates to the rapid expansion of China and India, and to a significantly better macroeconomic performance of LAC. Our focus in this section is on this last wave and, due to data availability, we restrict our attention to trade in goods. ${ }^{1}$

\section{A. The Big Picture}

Trade between LAC and Asia has been growing steadily over the past twenty years, with a brief contraction in 2009 due to the impact of the global financial crisis and some moderation since 2013 due to the decline of commodity prices (Figure 1). After being less than one percent of LAC's GDP at the beginning of the century, total exports of LAC to Asia reached around 3 percent of LAC's GDP in 2017 (peaking at nearly 31/2 percent of GDP in 2013). During the same period, LAC's imports from Asia went from less th an 2 percent to over 5 percent of GDP.

\footnotetext{
${ }^{1}$ Our a nalysis is ba sed on the United Na tion's COMTRADE statistics for the period 1997-2017, a dataset that
} only coves trade in goods. See the data appendix for a dditional information. 
Along with the larger export and import values, the shares of Asia in total LAC's imports and exports has also increased. These bigger shares largely mirror declines in shares of North America (U.S. and Canada). In particular:

- While just six percent of LAC exports went to Asia in the year 1998, the figure rose to almost 20 percent by 2017. The flipside of this tripling of the export share to Asia has been a reduction in the share to North America, which declined from 55 to 47 percent during the same period (Figure 2, Panel A). If we exclude Mexico, which is a major trading partner of the U.S. and Canada, the rebalancing of exports is even more marked. More specifically, the share of Asia to LAC (excluding Mexico) increases from 10 to 30 percent, while the share of North America to LAC (excluding Mexico) declines from 33 to 20 percent.

- A similar picture emerges for the imports of LAC from Asia, with the share increasing from 11 percent to 32 percent in the period 1998-2017, and the share of imports from North America declining from 50 to 34 percent (Figure 2, Panel B). Contrary to the case of exports, excluding Mexico from the sample depicts a slightly more homogeneous rebalancing of imports. In particular, Asia's import share goes up from 12 to 30 percent (similar to the full sample), but the flipside of this shift is more evenly distributed across regions - with relatively similar declines in the import shares of North America, Europe, and LAC itself.

Figure 1. LAC Exports/Imports/Trade-balance to/from/with Asia, 1998-2017

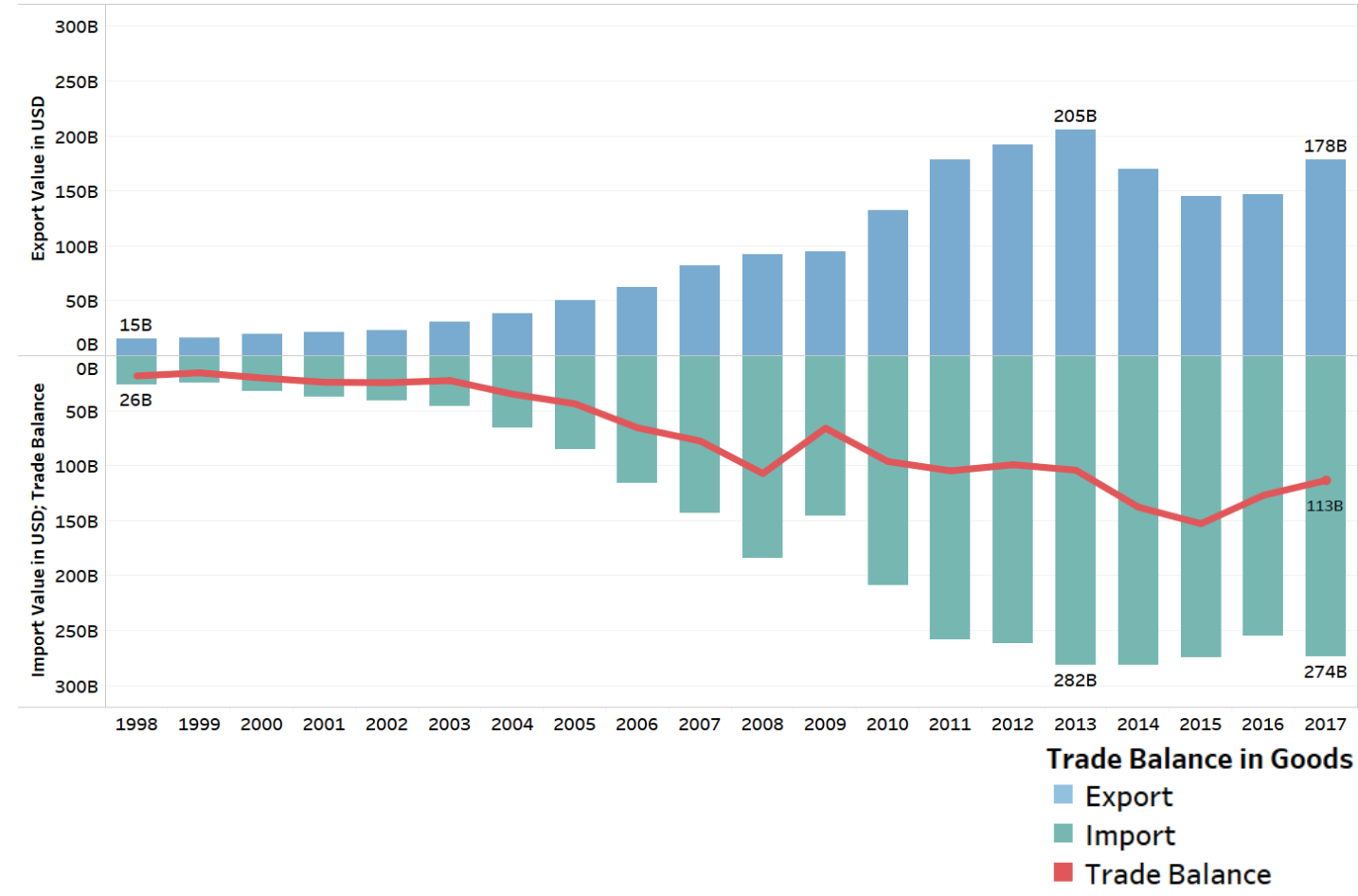

Source: United Na tion's COMTRADE data and IMF staff calculations. 
As discussed in the next two subsections, the growth of LAC's trade with Asia has been primarily driven by the expansion of China both as an export destination (mainly for LAC's commodities) and a source of imports (of manufactures). However, the progressive shift of China from an investment- to a consumption-led economy is likely to pose new challenges for LAC countries, as the deceleration of China's demand for commodities may have implications for LAC exporters. While the demand for soybeans and meat products may remain strong to support a growing urban population in China (Casanova et al, 2016), the demand for mineral intermediate inputs may decline over time. To sustain the linkages already built with China, LAC countries should diversify and increase the value added of their exports. Policies supporting trade integration and reducing trade costs could also facilitate this transition, as discussed in Section V.

\section{Figure 2. Geographical Distribution of LAC Exports and Imports, selected years}

Panel A. Export Shares, by Destination Regions
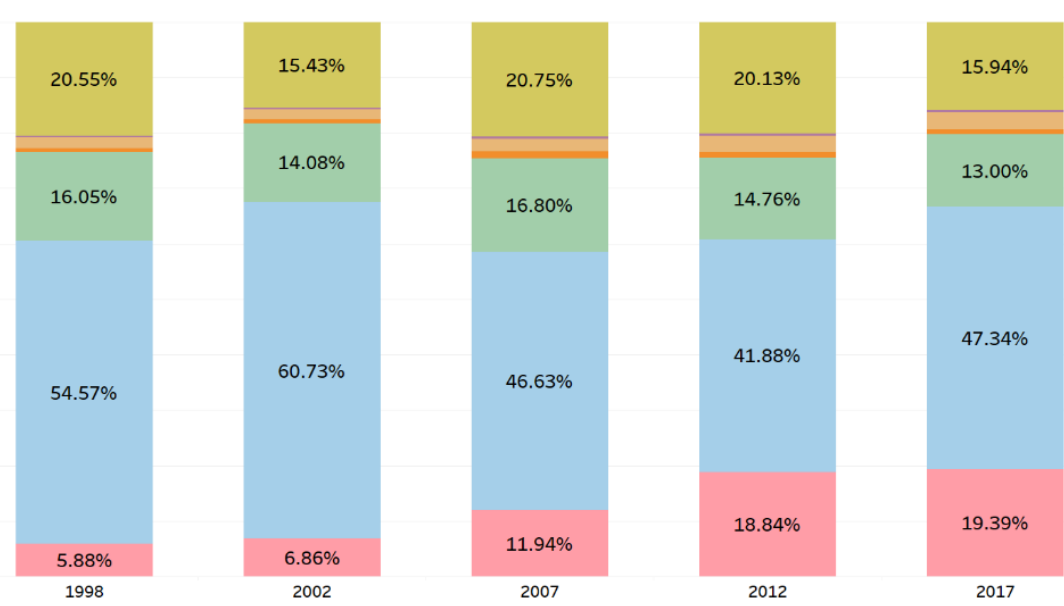

Panel B. Import Shares, by Regions of Origin
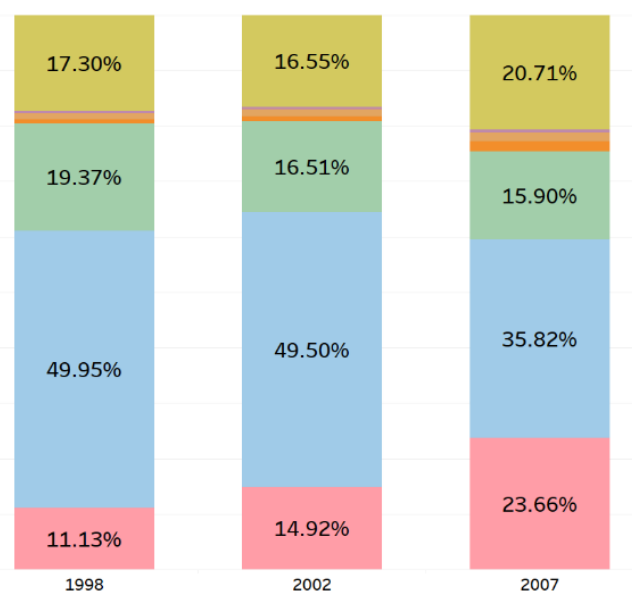

\section{Regions}

$\because \mathrm{LAC}$

- Oceania

= MENA

- Africa

Europe

- North America

- Asia

Source: United Nation's COMTRADE data and IMF staff calculations. 


\section{B. LAC's Exports to Asia}

LAC's exports to Asia are highly concentrated, in terms of both geographical destination and products. Regarding the former, 53 percent of total exports went to China in 2017, followed by Japan (11 percent), and India (9 percent). Regarding products, exports of minerals, metals, and fuels comprised nearly half of total exports to Asia in 2017, while exports of vegetables reached 20 percent.

This high degree of concentration has created strong bilateral links for key products. For instance, as shown in Figure 3, the trade of iron ores are largely a Brazil-China connection, although Peru and Chile as origins and Japan and South Korea as destinations also play a role. Similarly, for mineral fuels products, linkages exist between Venezuela, Brazil, Colombia, Mexico on the origins side and China, India, South Korea, Japan and Sigapore on the destinations side. Finally, trade in soy beans and other oil seeds is primarily a BrazilChina connection with a role also played by Argentina and Uruguay as origins. Trade in copper has Chile and Peru standing out asorigins, and China and South Korea as destinations.

The magnitudes of these linkages saw significant changes in a matter of fifteen years. In particular, Figure 4 shows that China was not a dominant destination for ores, mineral fuels and meat in 2002, while Ecuador and Argentina were significant sources in the mineral fuels and soya beans markets, respectively.

The high degree of concentration has led to an increase in LAC's export dependency from Asia, particularly for some of the largest economies in the region (Figure 5). ${ }^{2}$ Not surprisingly, the increase in export dependency has been linked to an increase in dependency from China. In particular, Casanova et al (2016) find that LAC's export dependency from China increased substantially, and across the board, from 2008 to 2014, with the highest dependency found for Costa Rica, Colombia, Uruguay, Venezuela, Brazil, Panama, Peru, Chile, Guyana, and Argentina. They also find that, for the largest exporters to China (i.e., Brazil, Argentina, Chile, Peru, Colombia, and Venezuela), the concentration was largely across four commodities: soy (soybeans, soybean oil), crude oil, copper (copper ore, copper cathodes, unrefined copper), and iron ore.

In the context of China's rebalancing process, which will be analyzed in more detail in Section III, countries with higher dependency from China will suffer the negative effects of changing Chinese demand patterns, particularly with respect to minerals and metals.

\footnotetext{
${ }^{2}$ LAC's export dependency from Asia is measured as the share of LAC exports to Asia as percentage of total LAC exports to the world.
} 


\section{Figure 3. LAC's Top-six Export Products to Asia by Origin and Destination, 2017}

Panel A. Origin

Metal Ores, slag and residues Mineral fuels and products Soy beans and other oil seeds Copper and articles thereof Meat and edible meat offal Food residues, animal fodder

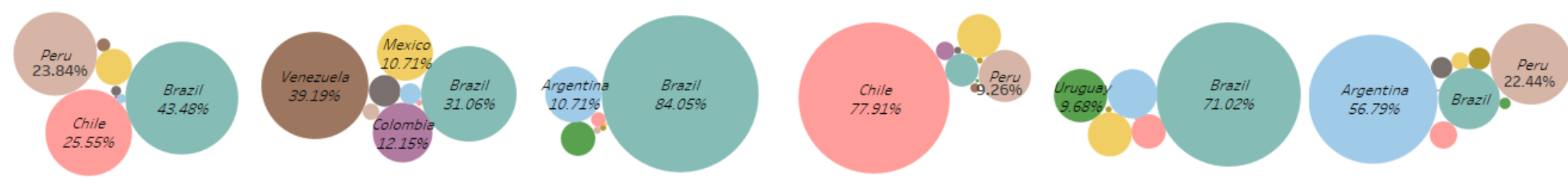

Panel B. Destination

Metal Ores, slag and residues Mineral fuels and products

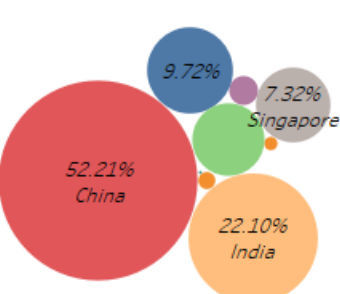

Soy beans and other oil seeds

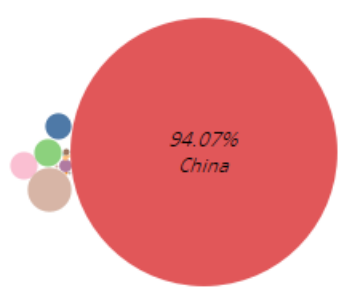

Copper and articles thereof

Meat and edible meat offal

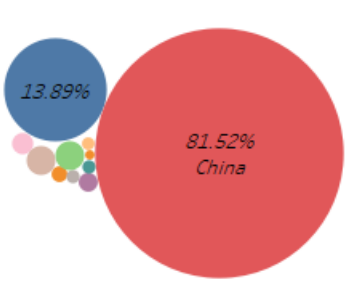

Food residues, animal fodder
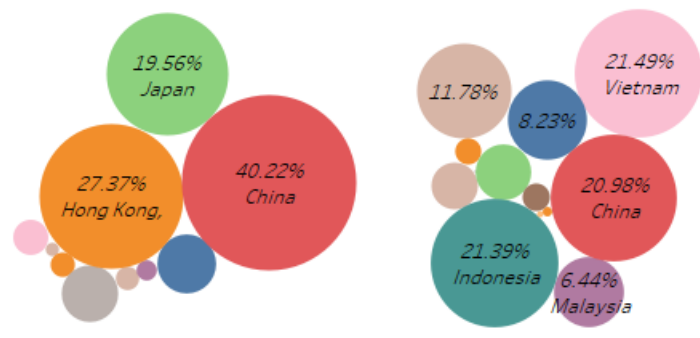

Source: United Nation's COMTRADE data and IMF staff calculations. 
Figure 4. LAC's Top-six Export Products to Asia by Origin and Destination, 2002
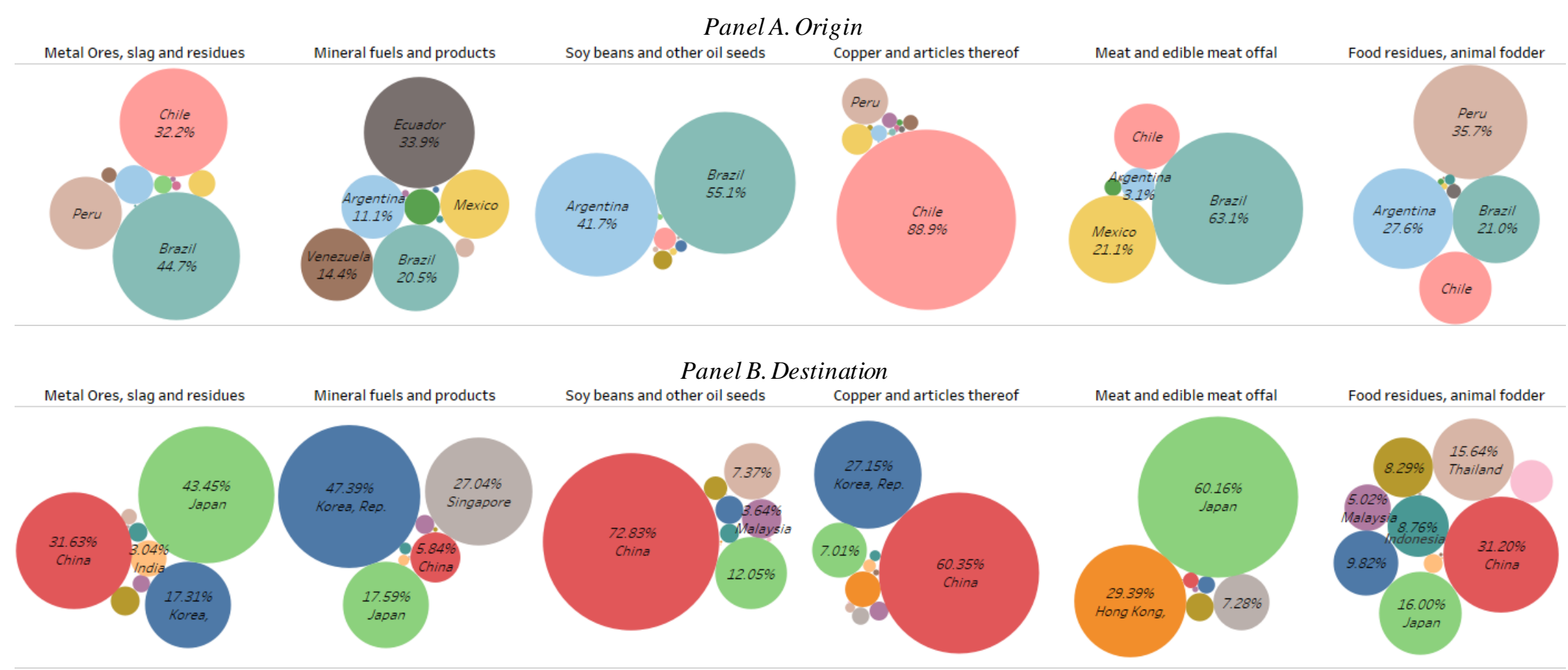

Source: United Nation's COMTRADE data and IMF staff calculations. 
Figure 5. LAC's Exports Dependency from Asia, 1997-2017

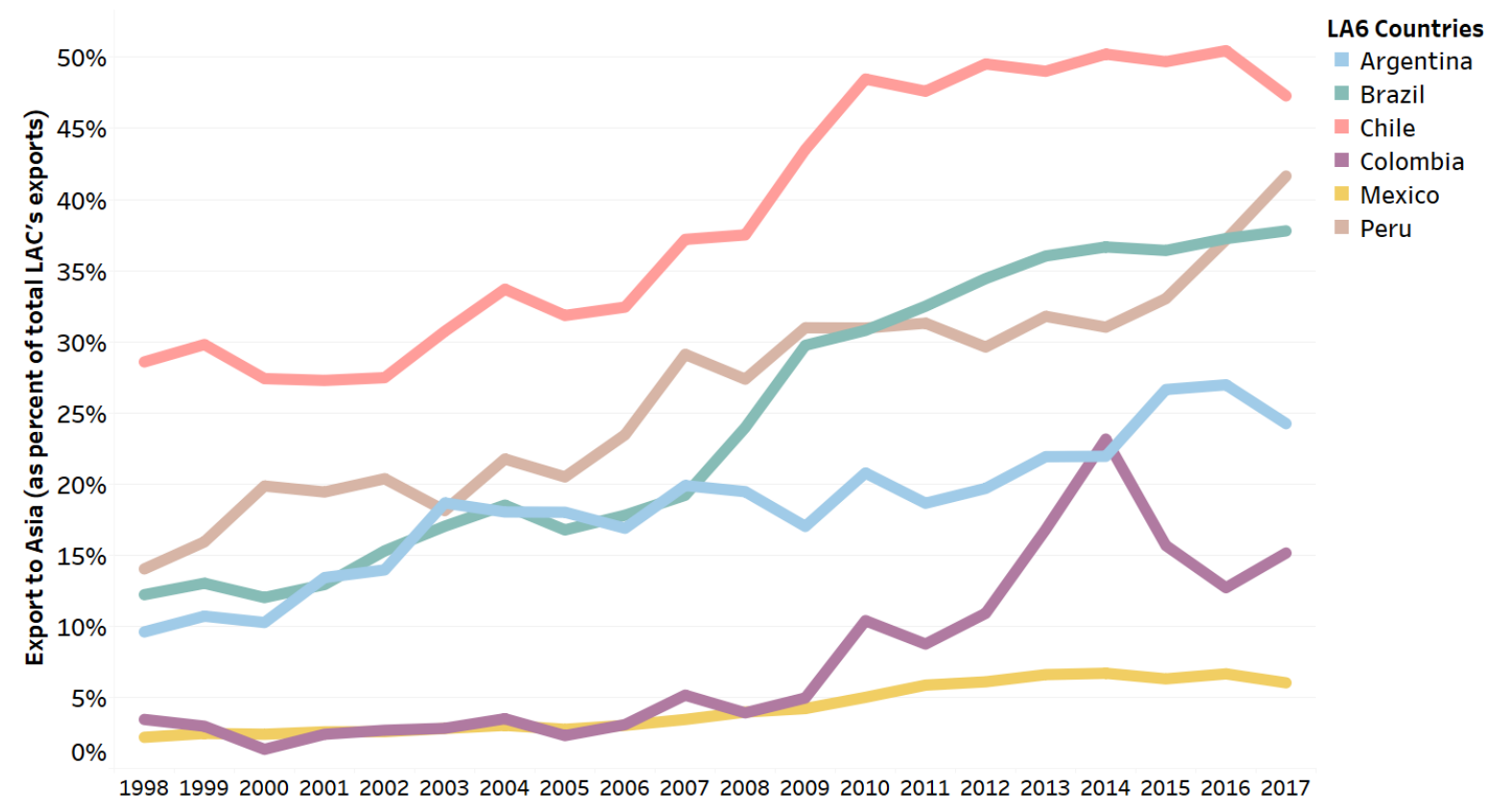

Source: United Na tion's COMTRADE data and IMF staff calculations.

\section{LAC's Imports from Asia}

The linkages through imports show both similarities and differences relative to those stemming from exports. On the similarities, China was also the main import origin in 2017 (57 percent), followed by Japan (10 percent), Korea ( 9 percent), and India ( 5 percent). There is also a high product concentration, with products such as machines and electronics or transportation vehicles exhibiting large shares. On the differences, it is important to highlight the role of Mexico, which imported nearly half of LAC's imports from Asia in 2017 while it accounted for just about 12 percent of LAC's exports to Asia. This feature of the LAC-Asia trade is driven by the special role that Mexico plays in the access to the North American market.

While China remains the main origin of imports in the largest product categories, the shares are not as concentrated as in the case of exports when it comes to key product groups (Figure 6). In particular, Japan takes the largest share in vehicles and accessories (30 percent), with Korea reaching 19 percent. Similarly, Japan and Korea also play significant roles in other categories, including iron and steel, optical equipment, and plastics. As indicated above, Mexico was the main imports recipient in most key categories, with non-negligible participation by Brazil and Chile in some categories. 


\section{Figure 6. LAC's Top-six Import Products from Asia by Origin and Destination, 2017}

$$
\text { Panel A. Origin }
$$

Electrical machinery equipme.. Nuclear reactors \& machinery Vehicles, parts \& accessories optical, photographic, Lenses Plastics and articles thereof.

Iron and steel
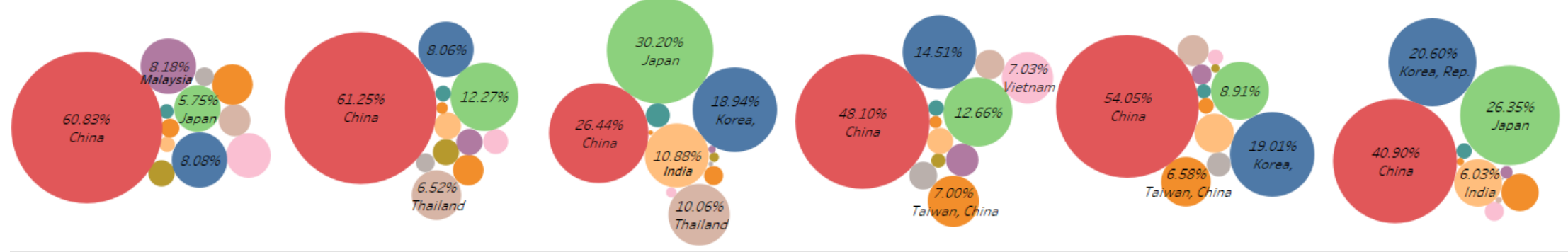

Panel B. Destination
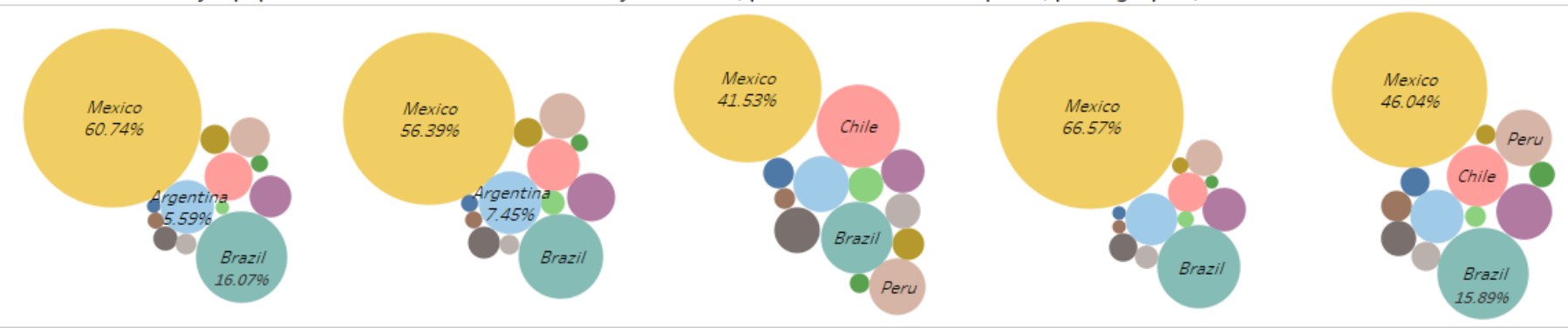

Iron and steel

Source: United Nations' COMTRADE data and IMF staff calculations. 


\section{Figure 7. LAC's Top-six Import Products from Asia by Origin and Destination, 2002}

$$
\text { Panel A. Origin }
$$

Electrical machinery equipme.. Nuclear reactors \& machinery Vehicles, parts \& accessories optical, photographic, Lenses Plastics and articles thereof.
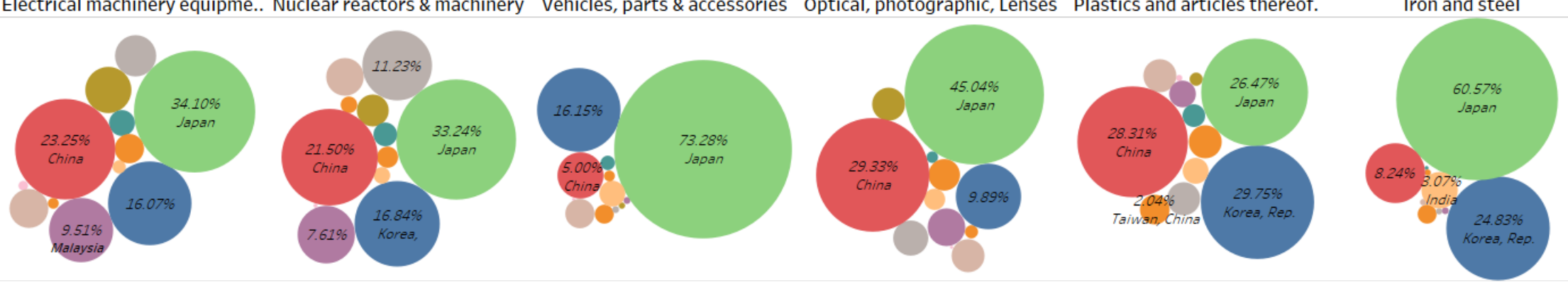

\section{Panel B. Destination}

Electrical machinery equipme.. Nuclear reactors \& machinery Vehicles, parts \& accessories optical, photographic, Lenses Plastics and articles thereof.

Iron and steel
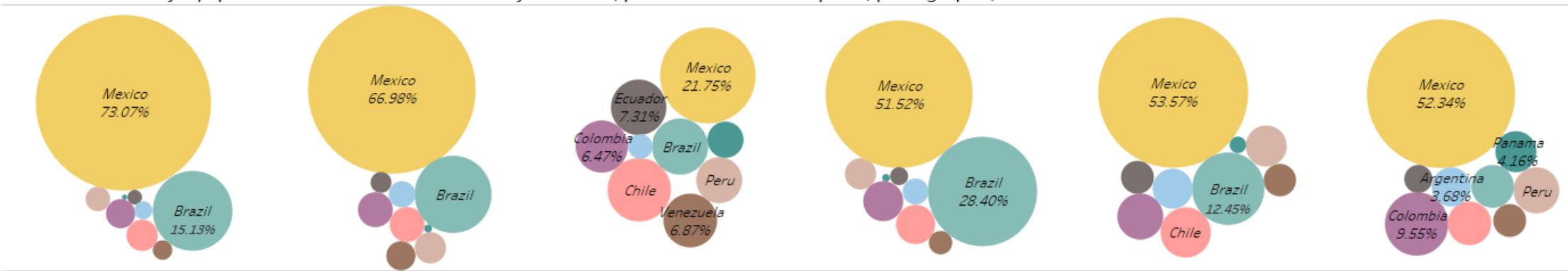

Source: United Nations' COMTRADE data and IMF staff calculations. 
As in the case of exports, China has increased its participation over the past fifteen years. As illustrated in Figure 7, the share of imports coming from China was below 30 percent in all categories in 2002, and in a couple of cases even smaller. The rise of China happened at the expense of Japan, which in 2002 used to have the largest share in all the major product categories, but in 2017 only has a prominent role in the vehicles market, and to a lesser extent in the iron and steel market.

\section{Asia-LAC Third-Market Competition}

While Asia and LAC have different export structures - with Asia being an exporter of manufactured goods and LAC and exporter of natural resources and/or agricultural products - there are nonetheless some common export categories. To as sess the extent of competition between the regions in given export markets, we calculate each region's participation in exports to North America, which is a common third market for them.

\section{Figure 8. Export Competition between LACand Asia in North America}

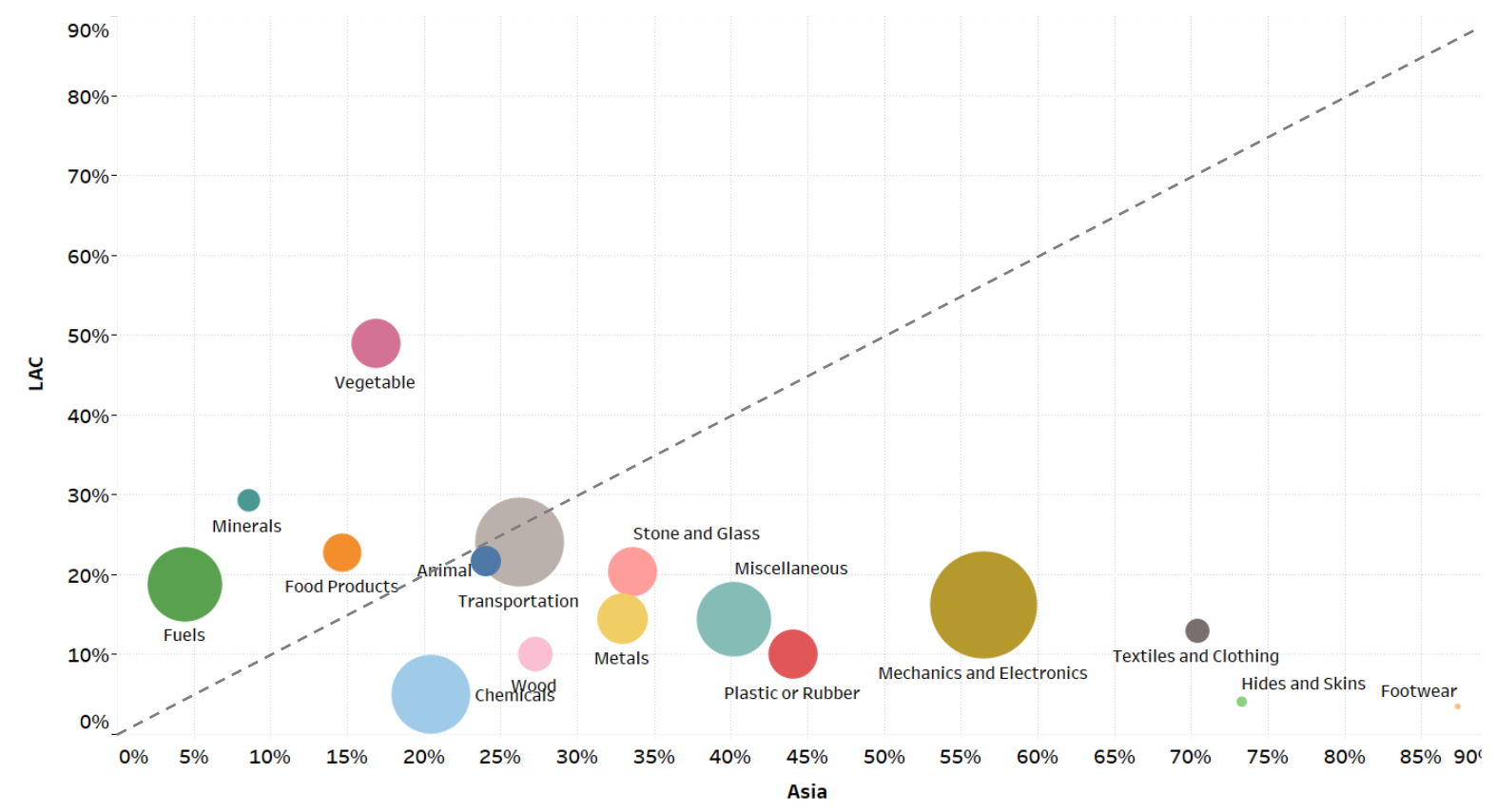

Source: United Na tions' COMTRADE data and IMF staff calculations.

Note: The variables in the $\mathrm{x}$ - and $\mathrm{y}$-axis are the market shares in Asia andLAC, respectively, in percent. The size of the bubbles represents the size of a given market in North America. Markets along the 45-degree line are those in which both LAC and Asia compete.

Figure 8 shows the market shares of Asia and LAC in North America for different product categories. The analysis should be done relative to the 45-degree line: the closer to the 45degree line, the larger the competition between the markets; the further away from the 45degree line, the more the "specialization" of each region in certain product categories. The chart shows that some products are only sold by LAC and others only sold by Asia, 
displaying a high degree of specialization. Consistent with the export structures of each region, LAC's export participation in North America is dominated by fuels, minerals, vegetables, and food products, while Asia's participation is dominated by manufactured products. There are only two categories, animal products and transportation — with LAC's participation in the latter dominated by Mexico - for which the shares of both regions are relatively similar, suggesting that in the U.S. most competition between the regions takes place in these categories.

More generally, and as will be shown in Section IV, over the past 20 years China has emerged not only as an important trading partner, but also as one of the top competitors for some of LAC export categories. China's retreat from certain markets, due to its ongoing rebalancing process, could open new opportunities for LAC exporters. However, other countries, such as India, are also trying to fill this gap and could undermine LAC's competitive advantage in some export markets.

\section{THE LONG-TERM IMPACT OF CHINA'S REBALANCING ON LAC}

China's rebalancing is occurring on several dimensions. In this section we consider two developments usually associated with the ongoing structural economic transformation of the Chinese economy. First, domestic demand is shifting away from investment and towards consumption as Chinese households become wealthier and their disposable income rises. Second, on the production side, services are outgrowing manufacturing, as the structure of production becomes more complex, integrated and higher-value added (Figure 9). ${ }^{3}$

\section{Figure 9. China's Rebalancing: Two Developments}
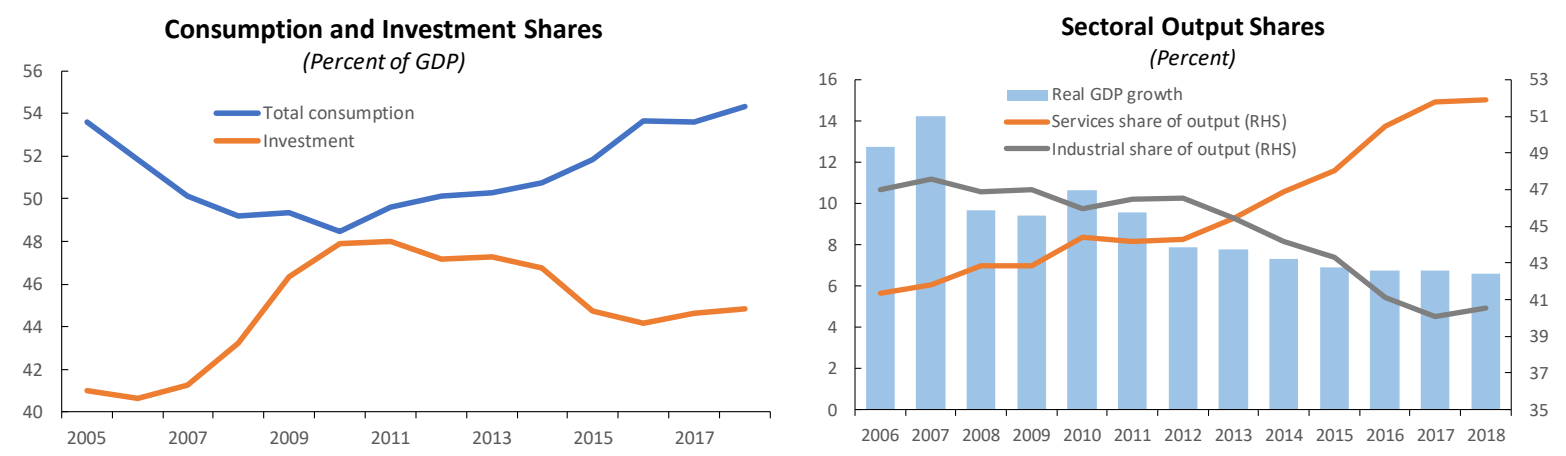

Source: Mano (2016), National Authorities and Haver Analytics.

We analyze this phenomenon through the lenses of a computable general equilibrium trade model. The long-run trade model simulates changes that capture the aforementioned trends

\footnotetext{
${ }^{3}$ The reba lancing process in China is a lso associated with a slowdown towards a more sustainable growth path. While the focus of the paper is on the rebalancing ra ther than on the slowdown, a reduction in China's economic growth is embedded in the model by a ssuming a shift from manufacturing to services, which implies a reduction in a verage productivity. However, the overall ef fect of the rebala ncing on LAC exports does not only depend on what happens in China; it depends on theeconomic performance of other countries with la rge markets (e.g. India) and on the a bility of LAC to diversify out of China and into other markets. We explore some of these indirecteffects in this section.
} 
related to China's rebalancing, and is then used to assess the impact on the rest of the world, particularly LAC. Presumably rebalancing would happen against a backdrop of continued growth of the Chinese economy in the medium-term. In this paper, though, we focus only on changes in the composition of China's economy to isolate how those could impact LAC.

\section{A. LITERATURE ON SPILLOVERS FROM CHINA}

The empirical literature has resorted to a variety of methodologies to study the spillover effects from China, including GVAR (IMF, 2014; Cashin et al, 2016), VAR (Hong et al, 2016; World Bank, 2016), factor-augmented VAR (Ahuja and Myrvoda, 2012), panel regressions (Ahuja and Nabar, 2012), and network analysis (IMF, 2011; Kireyev and Leonidov, 2016). In general, these studies have focused on reduced form relations between aggregate variables, and in this context rebalancing is often equated to a drop in either China's total GDP or some of its components.

Another commonly used approach is the analysis of impulse responses from dynamic stochastic general equilibrium (DSGE) models. There are a variety of models considered by this strand of the literature: the G40 model as in IMF (2014), the GIMF as in IMF (2010), and the FSGM as in Dizioli et al (2016) or Anderson et al (2015). These models focus on the behavior of aggregate variables. Using a similar methodology, IMF (2014, 2016a, 2016b) study the effect of financial spillovers.

A new strand of literature, which uses trade models to quantify spillovers from shocks in China, has developed relatively recently. These papers, including Hsieh and Ossa (2016) and Di Giovanni et al (2014), follow the seminal work of Melitz (2003) and Eaton and Kortum (2002). Trade models of this type are well suited to capture rich input-output interlinkages, ${ }^{4}$ as well as extensive international production value chains, which nowadays dominate world trade. Caliendo et al (2017, CFRT hereafter) develop a computable general equilibrium model incorporating these features. ${ }^{5,6}$ Other models featuring firm heterogeneity and supplychain trade include Costinot and Rodriguez-Clare (2014). Building on the analysis done by Mano (2016), but focusing on the spillovers on the LAC economies and using CFRT's model, our paper adds to this growing literature.

\section{B. A MODEL TO ASSESS THE LONG-RUN EFFECTS OF CHINA'S REBALANCING}

Our simulations rely on the multi-sector computable general equilibrium model developed by CFRT. The model puts together several recent advances in the modelling of international trade. Most notable among them are the assumption s that firms within each sector are heterogeneous in their productivity, and that international trade arises in the context of cross-

\footnotetext{
${ }^{4}$ Ca liendo and Parro (2015) argue that accounting for this input-output structure is crucial for their counterfactual exercise. The same logic applies to the shocks studied in our paper as well.

${ }^{5}$ The approach to intermediate-input trade used in CFRT was originally developed by Caliendo and Parro (2015).

${ }^{6}$ Caceres et al(2019) use this model to study potential global trade scenarios.
} 
border input-output relationships. ${ }^{7}$ This means than in the simulations, firms may enter or exit export markets in response to shocks. Likewise, trade in intermediate inputs should arguably be part of any model that aims to assess the potential effects of shocks in a world with long and complex global supply chains. This means changes in the competitive landscape across sectors are modeled in a rich way: wages, the cost of inputs and trade barriers define a given exporters's sectoral cost base that is then factored in the sourcing decision of any importer. Changes in trade costs, structure of production, productivity, preferences and income will all materially affect the network of trade and will endogenously lead to the formation of new value chains.

CFRT's modeling framework is subject to some limitations, present in most existing trade models. ${ }^{8}$ First, the model focuses on the trade channel alone, which has been identified as an important channel, but is not unique. ${ }^{9}$ Second, the model does not account for investment. This is important as changes in capital accumulation, which could be prompted by episodes of closing off to trade, can lead to inter alia changes in productivity, thus affecting output over the medium and long term. Third, the model abstracts from dynamics, thus ignoring transition costs, which may be sizable and could further exacerbate the magnitude of the implied spillovers. Lastly, as a by-product of the lack of dynamics, overall trade balances are assumed fixed. Since the model is static and only allows for comparisons between pairs of steady states, it is unable to explain non-zero trade balances (which are intertemporal in nature). ${ }^{10}$

A key feature imbedded in CFRT's calibrationis that there is significant trade diversion in equilibrium. CFRT is a long-term frictionless model, and thus its structure of value chains responds strongly to large shocks, often with signficant implications for individual countries and/or sectors. Typically, prices and wages adjust so that, if a country loses competitiveness in a given sector following a shock, it gain s competitiveness in other sectors where there was already some installed capacity. This is reinforced by the fact that the model features firm entry, which allows for the emergence of fundamentally new clusters of economic activity. However, these activities are the result of a newly found comparative advantage, which also depends on (i) the country's underlying productivity and trade barriers in a given sector as well as in the other sectors supplying it with inputs; and (ii) the productivity and trade barriers of the same sector in competitor countries.

\footnotetext{
${ }^{7}$ Firm heterogeneity, as in Melitz (2003), has been found to ex plain various features of the trade micro-data, such as within-industry reallocation of resources in the wa ke of trade libera lization (for a survey, see Melitz and Redding, 2014).

${ }^{8}$ Exceptions to this include Eaton et al(2016), Reyes-Heroles (2016), and Ravikumar et al(2019).

${ }^{9} \mathrm{IMF}(2016 \mathrm{a})$ argues that, while the tra de channel remains crucial to understand spillovers, the financial channel is becoming increasingly important, particularly after the global financial crisis. The financial channel could serve as an additional a mplifier of the shocks studied here.

${ }^{10}$ This shortcoming may not be as serious as it may a ppear at first. From a conceptual viewpoint, there is overwhelming evidence that macroeconomic fundamentals are far moreimportant than sectoral and bilateraltra de policies (including tariff changes) in determining countries' overall sa ving-investment balances (see IMF, 2018 and IMF, 2019). From a practical point of view, dynamic models that allow for endogenous changes in overall tra de balances have found a rela tively muted effect on these, even under large changes in tariffs (see IMF, 2019).
} 


\section{DATA AND CALIBRATION}

This paper builds on the dataset created by Caceres et al (2019). It combines the Eora global supply chain database ${ }^{11}$ with the 2015 applied-tariff data from UNCTAD's Trade Analysis Information System, accessed through WITS. The intersection of both databases results in a combined input-output database, with 17 sectors and 165 countries. This database enables the analysis of all bilateral exposures - among the 165 countries-at the sectoral level. Table 1 lists the 17 sectors included in our analysis.

Table 1: Economic sectors included in the analysis

\begin{tabular}{ll}
\hline Goods & Services \\
Agriculture & Construction \\
Extractiveindustries & Wholesale and retail trade \\
Food & Hotels and restaurants \\
Textile & Transport and communication \\
Wood and paper & Financial services \\
Chemicals and oil derivatives & Other services \\
Metals & \\
Electronics & \\
Transport goods & \\
Other manufacturing & \\
Electricity & \\
\hline
\end{tabular}

\section{THE LONG-TERM IMPACT OF CHINA'S REBALACING}

In this section, we map the two dimensions of China's rebalancing described previously into shocks in the model, and compute the resulting spillovers for LAC economies. Spillovers are calculated on a ceteris paribus basis, i.e. in the case of no other concurrent events taking place besides the original shock. Crucially the scenarios do not take into account policy responses. Since the model captures only long-term changes in the production and consumption structure of each economy, demand management policies like fiscal and monetary stimulus would anyways not be relevant. However, responses that operate in the long-term and affect potential GDP, such as structural reforms or industrial policy, would be relevant additions to any effects found here.

\section{i. Scenario Definition}

China's rebalancing is modeled as a combination of a "preference shock" and a "production shock" (denoted as "combined shock"). The "preference shock", which captures the shift in domestic demand from investment to consumption, is introduced as a change in the preferences over different types of goods or sectors in China, i.e. a change in the share of each sector in final consumption. The "production shock", which captures the transition from

\footnotetext{
${ }^{11}$ The Eora global supply chain database consists of a balanced multi-region input-output (MRIO) ta ble linking 26 sectors a cross 190 countries, with a complete annual time-series over the period 1990-2015. See Lenzen et al (2013) for a detailed description of the Eora database. Our tra de-flow data correspond to the la test - 2015Eora table.
} 
manufacturing to services as production becomes more complex and integrated, is modeled as a change in the intermediate production structure, i.e. in the shares of each sector in the input structure of the other sectors. Both shocks are assumed to happen simultaneously. Note we do not study an aggregate shock, such as a productivity shock, and hence focus only on compositional changes to the Chinese economy. The size of the Chinese economy is impacted in general equilibrium only through shifts in preferences and production technology. Finally, the model is static and thus the simulations we study are comparisons across steady states. Appendix II shows the impact of each shock separately, concluding that the "preference shock" is by far the most significant.

The "preference shock" assumes that the preferences of Chinese consumers change to match the preferences of U.S. consumers in the base year. In practice, this involves replacing China's initial sectoral shares in final consumption by those of the U.S. As shown in Figure 10 - Panel A, such a change would imply a reduction in the share of goodsproducing sectors in final consumption by almost half. When looking into specific sectors, the shock involves reducing the share of sectors such as electronics or construction and increasing the share of sectors such as financial services or other services (Figure 10 - Panel B).

Figure 10. Calibration of the "preference shock"

Panel $A$

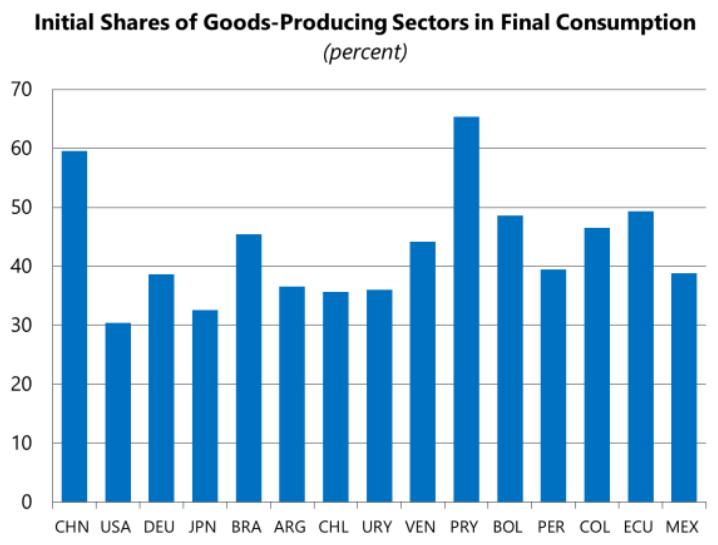

Panel B

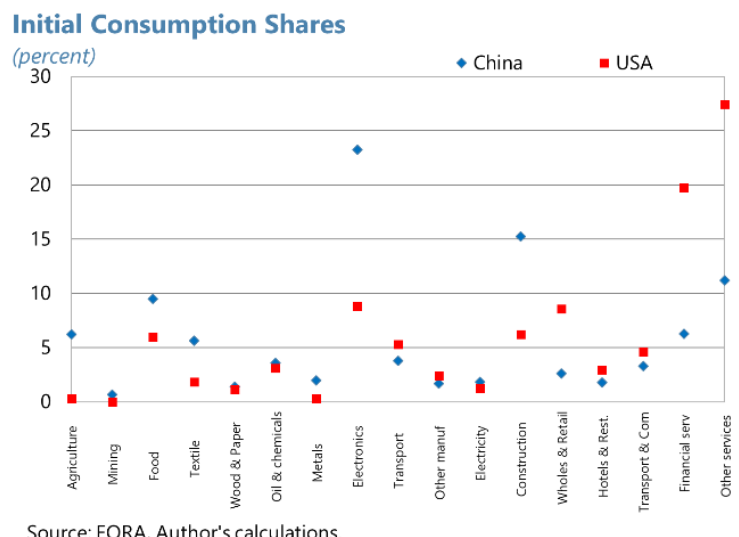

Source: EORA, Author's calculations.

Sources: EORA, IMF staff calculations. Goods-producing sectors a re those reported in Table 1.

The "production shock" assumes that the Chinese intermediate production structure changes to match the one of the U.S. in the base year. This implies replacing the shares of each sector in the input structure of the other sectors in China by those in the U.S. The change in the value of the shares is reported in Figure 11. In general, the share of service-producing sectors (particularly financial services) in the production of other sectors tends to increase, while the one of good-producing sectors tends to decrease. 


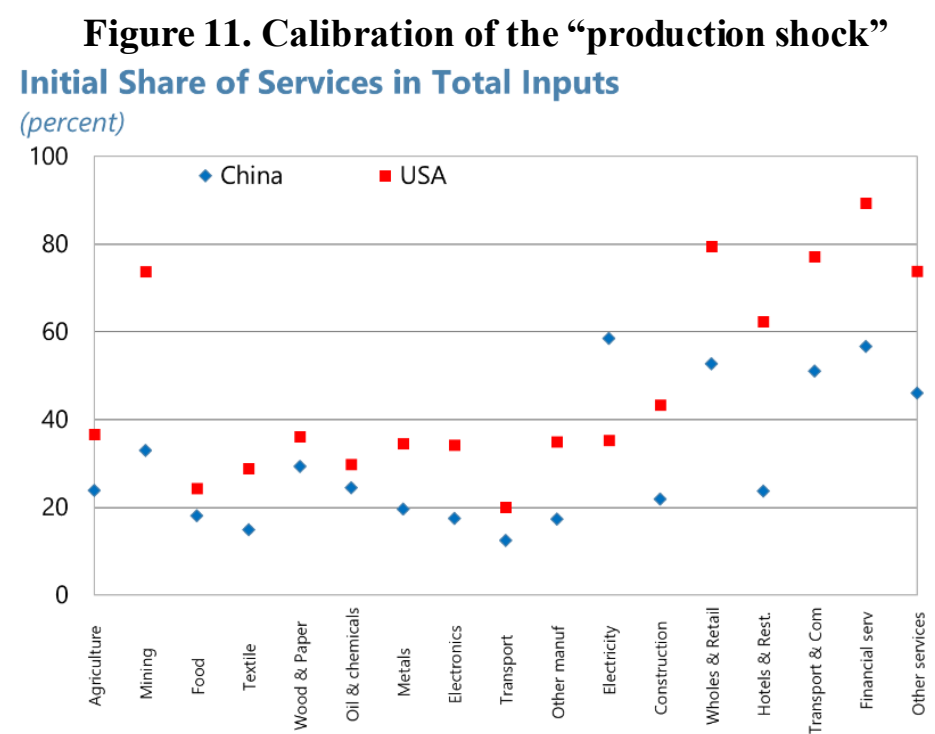

Source: EORA, IMF staff calculations.

Note: This chart shows the share of services in the total inputs into each sector in China and theU.S. The production shock is calibrated such that the shares in China become the same as those in the U.S. for ea ch sector.

\section{ii. What if China consumes and produces like the U.S.?}

China's rebalancing has a negligible impact on LAC's real GDP, but the effect is heterogeneous across countries and entails significant sectoral reallocations, giving room for winners and losers. In terms of changes in real GDP, relative to the situation of no rebalancing, many LAC countries are negatively affected by China's economic transformation, displaying declines in their real GDP (Figure 12, Panel A). This is particularly true for Paraguay and Bolivia, and Colombia. The exceptions are Mexico, Venezuela, and the Central American economies. They all exhibit increases in their real GDP following the shock. Overall, China' rebalancing implies an increase in LAC's real GDP by 0.1 percent. $^{12}$

LAC countries' real exports are marginally positively affected by China's economic transformation, exhibiting some heterogeneity across countries. LAC's real exports increase by 0.8 percent following the shock. The exports of Mexico, CAPDR, Ecuador, Paraguay and the Southern Cone countries increase following the shock. These countries seem to be competing against China in certain markets. China's rebalancing entails a retreat from some markets, giving an opportunity for these LAC exporters. But this is not true for all countries. China's rebalancing has a negative effect on the exports of Peru, Bolivia and Colombia, and to a lesser extent on the exports of Brazil and Venezuela (Figure 12, Panel B).

\footnotetext{
${ }^{12}$ The results are not driven by the choice of benchmark. This exercise wa s also done using Brazilas benchmark, and the results are not significantly different from those using the U.S. as benchmark, meaning that the differencein the structure of consumption and production between Brazil and the U.S. is much smaller than the difference between either of them and China. Results using Brazil a s benchmark are reported in Appendix I. Furtherm ore, because rebalancing is a slow-moving process, it may be more a ppropriate to imagine that China's economy will resemble more the U.S. than Brazil in twenty years.
} 
Figure 12. Effect of China's rebalancing

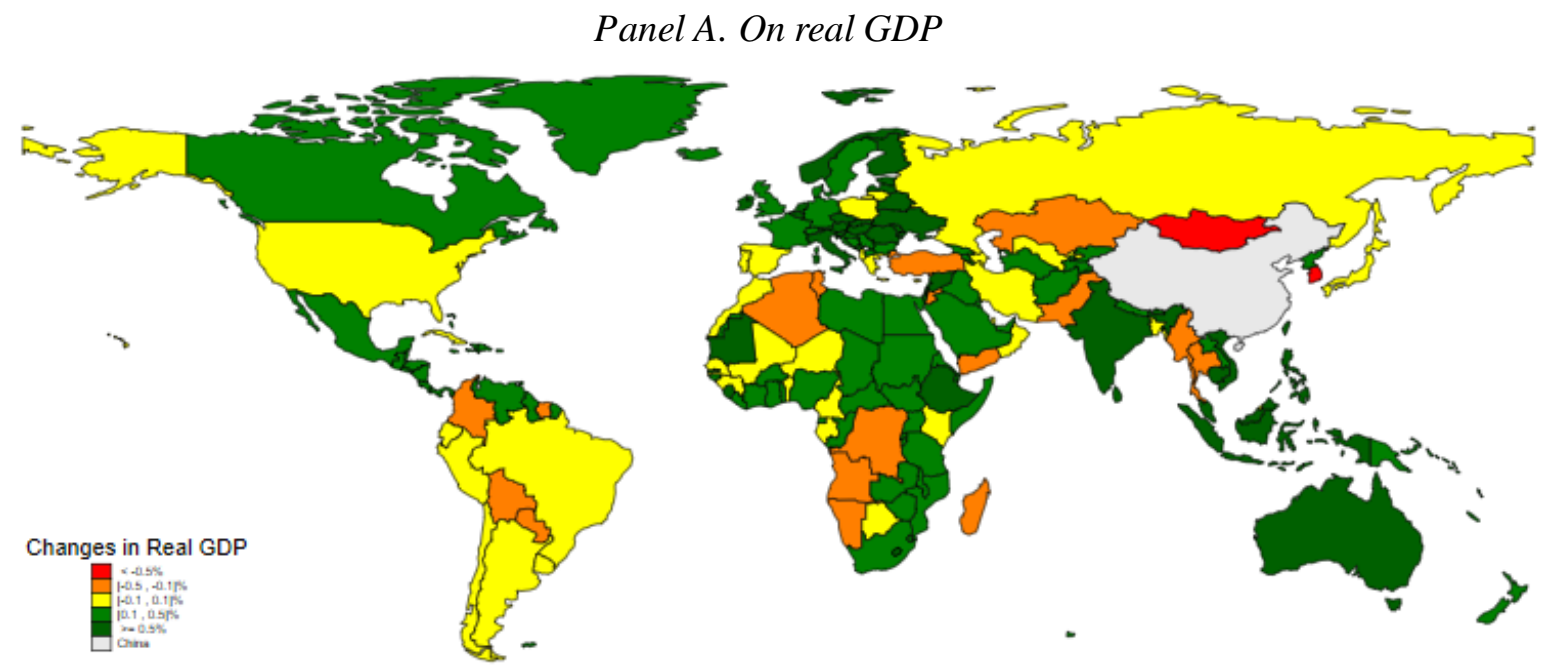

Panel B. On real exports of goods and services

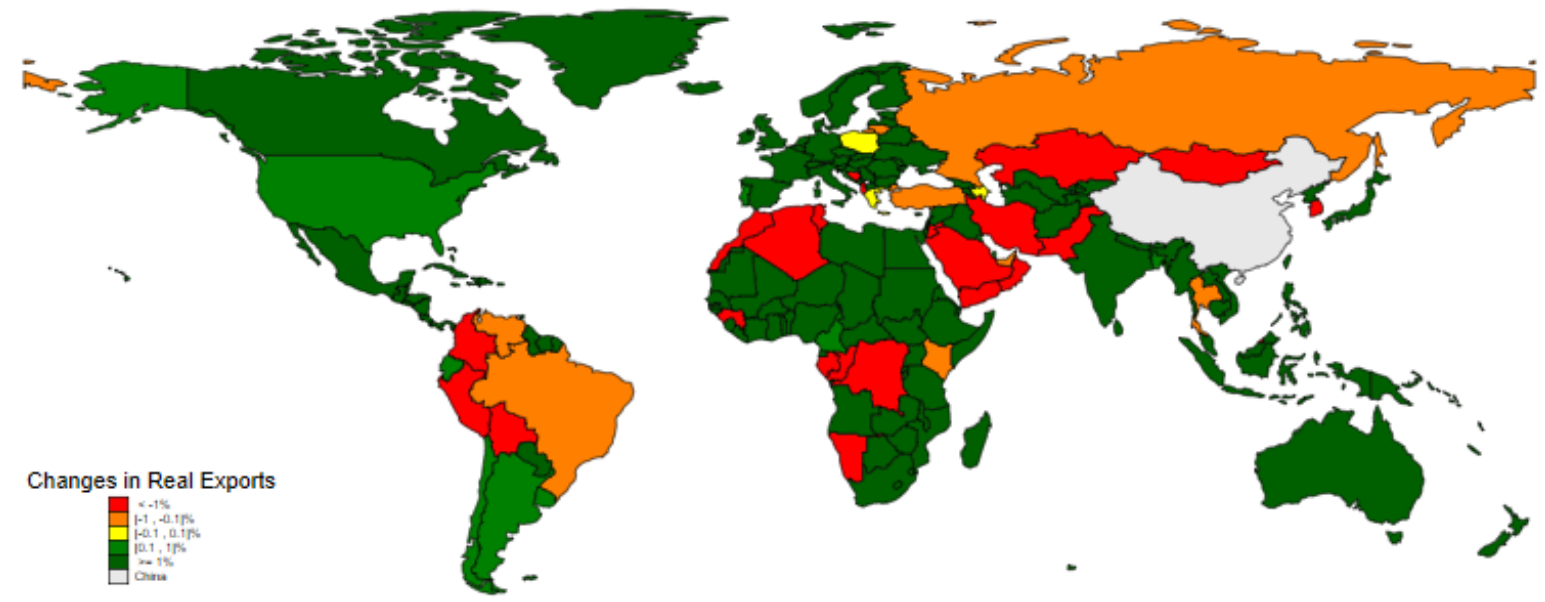

Source: IMF staff calculations. The figures show theeffect of the combined shock using the U.S. as benchmark. 
Both China and LAC experience a massive sectoral reallocation. China currently displays absolute and comparative advantage in many goods-producing sectors while it is much less competitive in services. As Chinese demand and production rebalance towards services, its comparative advantage shifts away from goods-producing sectors towards services. Figure 13, Panel A, shows that the sectoral GDP of financial services, other services, and wholesale and retail trade more than double, while the GDP of most goods-producing sectors declines. In response to this structural change, LAC countries adapt their productive structures either to fill the gap left by China in certain goods markets or to satisfy the Chinese demand for new products and services. This is the case of LA5, which on average reduce their mining production by more than 20 percent and increase the production of other products such as metals, electronics and transport (Figure 13, Panel B).

As a result, the composition of exports from some LAC countries changes substantially following the shock (Figure 14). Some countries fill the gap created by China's reduced comparative advantage in goods-producing sectors. Mexico, Argentina, Uruguay and the CAPDR countries, which currently have comparative advantage in goods-producing sectors, are the best candidates to pick up the space created by China's retrenchment in those sectors. Other countries, typically those that are highly exposed to China in very specific sectors such as Venezuela, Peru, Ecuador, Bolivia, Chile and Paraguay, see large falls in their terms-oftrade and experience the largest adjustment in equilibrium wages. Consequently, the comparative advantage in these countries shifts towards services, which are less intensive on intermediates and more labor-intensive. This effect is reinforced by China's increased demand for services, and thus both supply and demand factors push these countries to produce more services. Exports of services rise, particularly tourism, transport and communications, at the expense of exports of goods. ${ }^{13}$ Finally, a few countries are in between, such as Brazil and Colombia. These don't have particular strong initial comparative advantage in goods and are also not heavily affected by China rebalancing and thus experience small declines in both their goods and services exports.

The behavior of real exports at the sectoral level reflects losses in China's competitiveness in certain sectors. This model features two main channels. On the one hand, China loses competitiveness in some sectors, benefitting LAC countries that had a comparative advantage in those sectors. Electronics and textiles are two prime examples, with Mexico and Uruguay benefitting respectively from diminished Chinese competition in those two sectors. On the other hand, China is also importing less from and increasing its competitiveness in some sectors. Key sectors in this category include mining and oil extraction, and manufacturing of metals. LAC exporters with a comparative advantage in these sectors are Venezuela, Bolivia and Peru. These differences explain why Mexico and Uruguay for example gain in terms of real exports in the rebalancing scenario, while Venezuela, Bolivia and Peru do not.

\footnotetext{
${ }^{13}$ The final effects on services ex ports are a function of two factors: (1) the overall decline in terms of trade in ea ch country; and (2) the initial comparative a dvantage on producing services. For example, Venezuela's terms of trade drop by relatively more than other countries and because Venezuela has a la rger proportion of services in its exports to begin with compared to other similarly affected countries, its real services exports surge in the China rebala ncing scenario.
} 
Figure 13. Sectoral reallocation in China and LAC

Panel A. China

China: Changes in Real Sectoral GDP

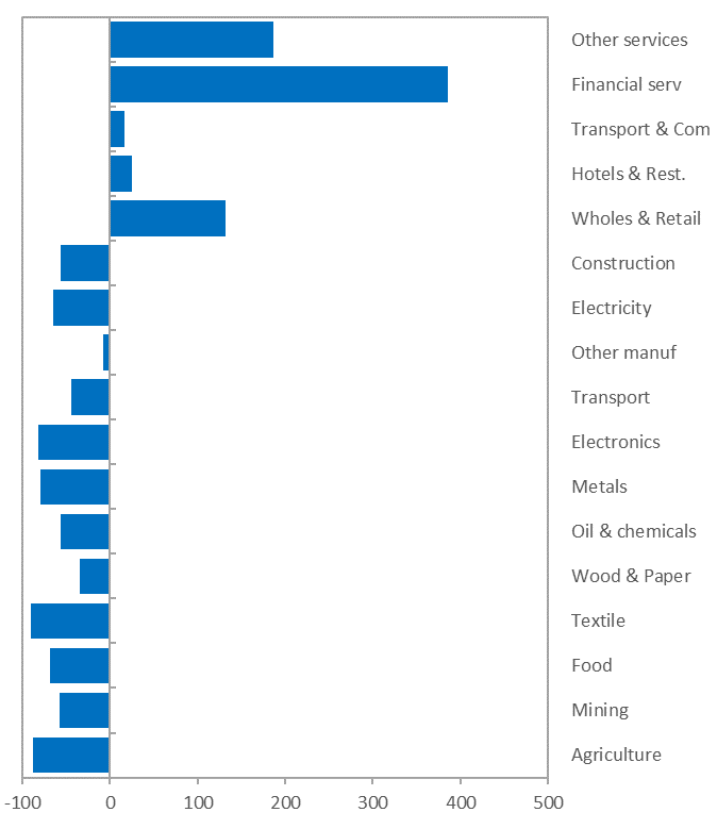

Panel B. LA5 Average

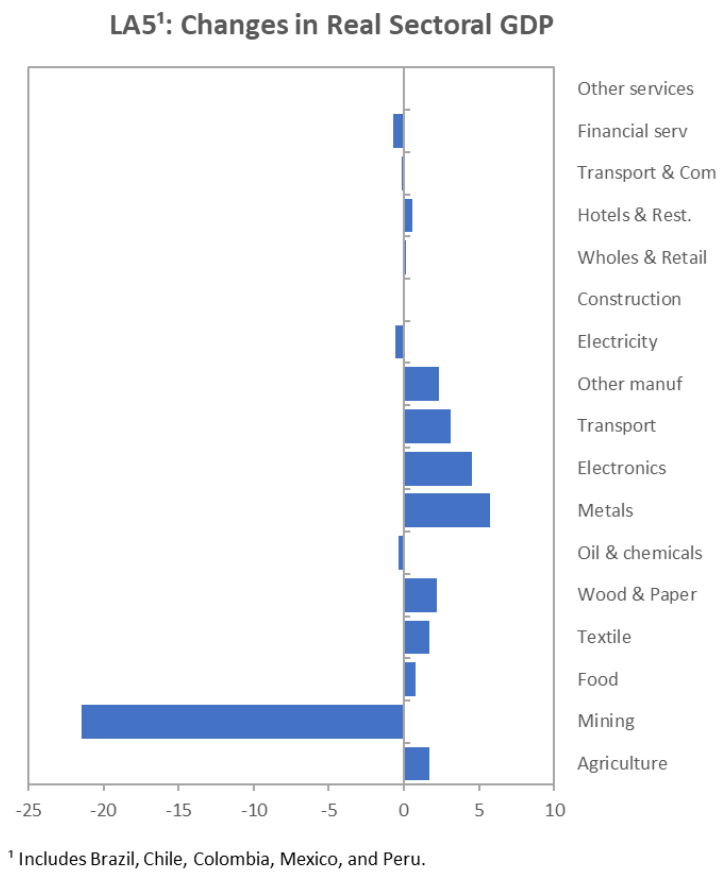

Source: Author's calculations. Thefigures show the effect of the combined shock using the U.S. as benchmark.

Figure 14. Effect of China's rebalancing on the composition of LAC's real exports

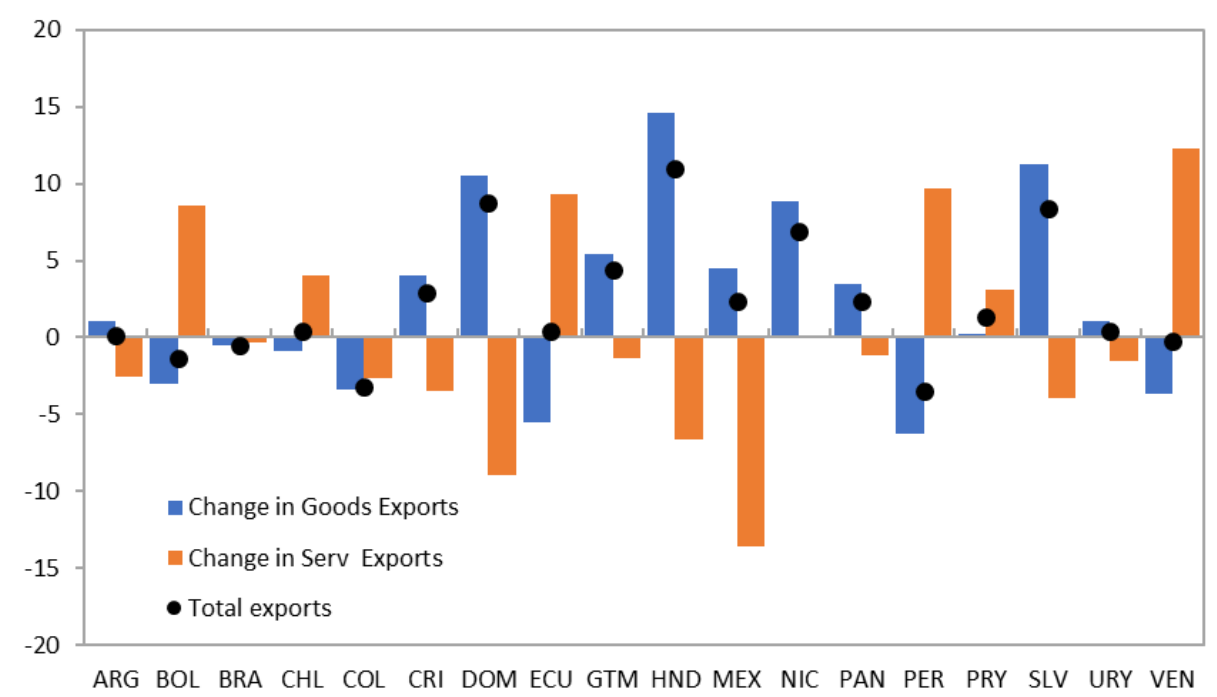

Source: IMF staff calculations. The figure shows the change in total real exports, real goods exports and real services ex ports a s result of the combined shock, using the U.S. a s benchmark. 
To further explore the adverse impact of China rebalancing, we split countries into commodity-intensive producers and others. Figure 15 shows the range of change in overall real GDP and the range in the contribution of mining and extraction activities to this change, across the two groups. The impact of China rebalancing is clearly different for commodity and for non-commodity exporters. While commodity exporters have a median fall in overall GDP of -0.1 percent, non-commodity exporters actually benefit from the shock. While the magnitudes seem small, they hide a massive fall in the mining sector for the first group, which contributes in some cases more than 1 percentage points. These concentrated losses explain why countries like Bolivia, Suriname and Paraguay see larger contractions of economic activity. Still, recall that our analysis is based on a long-term frictionless model, which implies that the transition costs behind the results might be understated.

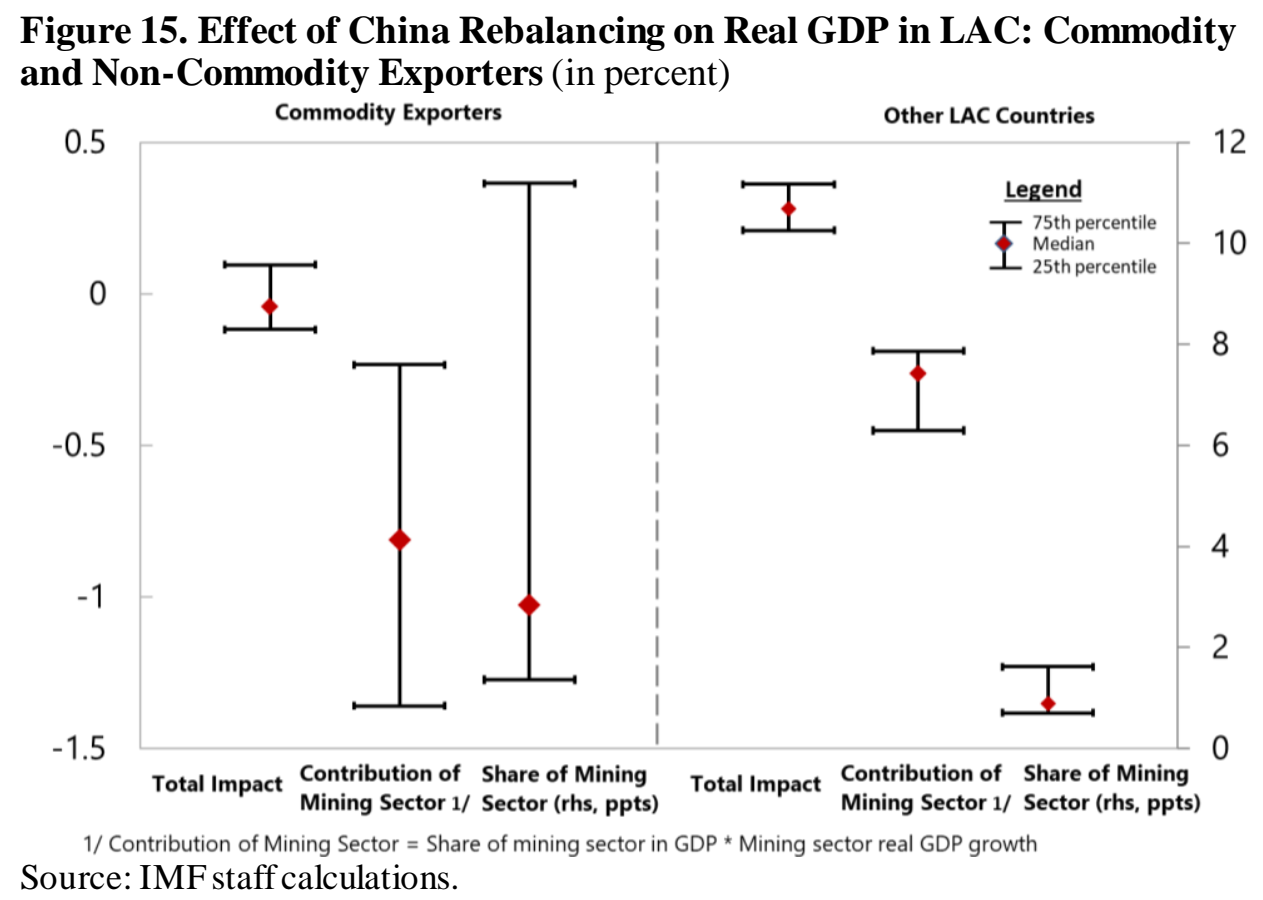

To gauge the extent of the possible reallocation costs, Figure 16 shows the share of sectors that see meaningful GDP contractions and labor reallocation, the latter measured by the loss of employment in percent of each country's initial labor force. The takeaway again is clear: countries that are initially more dependent on mining and ex traction activities suffer a disproportionate adjustment, with many seeing close to a third of their economies contracting, and a labor reallocation of more than 1 percent of their initial labor force. The silver lining is that, since losses are concentrated in commodity sectors, which are usually less labor-intensive, the losses from labor reallocation tend to be smaller than those from GDP contractions in most countries.

For these reasons, we can expect costly transitions in the short-term at least for countries that are initially more exposed to commodities, particularly if China is an important importer. 
Figure 16. Adjustment Cost to China Rebalancing in LAC: Commodity and Non-Commodity Exporters (in percent)

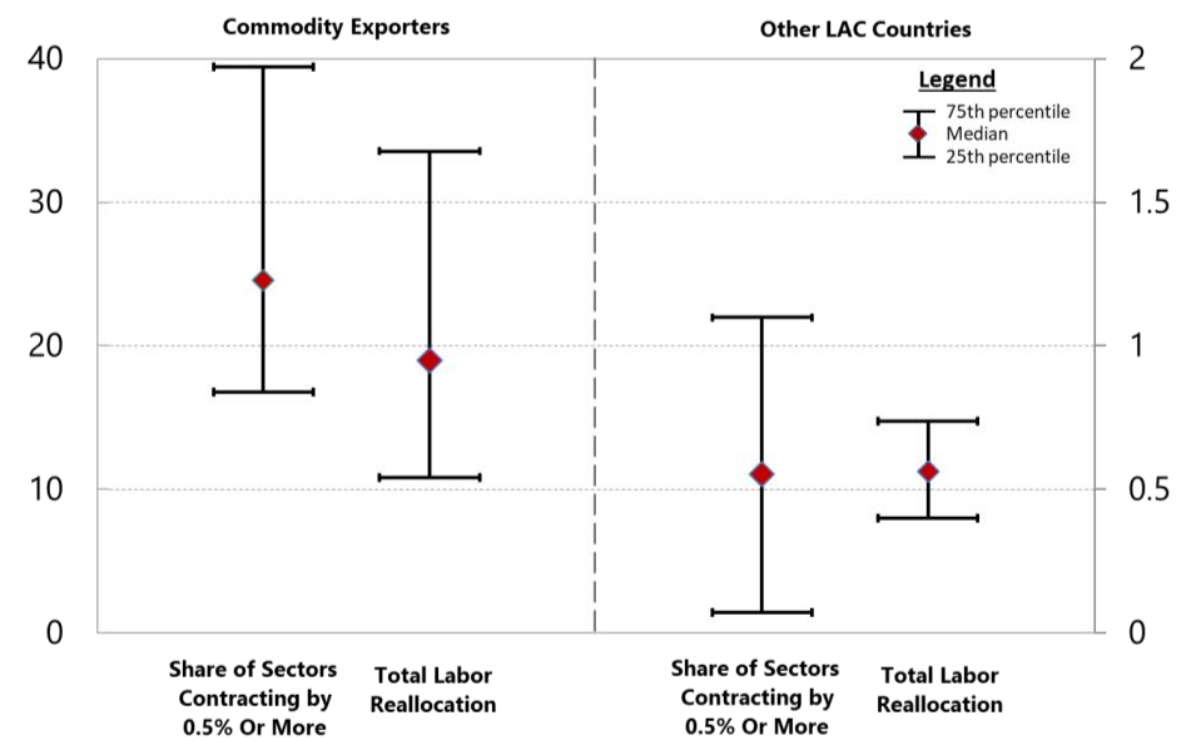

Source: IMF staff calculations.

Note: "Sha re of Sectors Contracting by $0.5 \%$ or More" represents the combined weight in GDP of a ll sectors that see their sectoral real GDP decline by at least $0.5 \%$. "Total La bor Rea llocation" represents the amount of la bor that needs to exit contracting sectors in percent of initialtotal employment.

\section{THE IMPACT OF CHINA'S REBALANCING ON LAC'S COMPETITIVE LANDSCAPE: A MISSED OPPORTUNITY?}

\section{A. CHINESE COMPETITION IN THIRD MARKETS}

China's retreat from certain markets as a result of its rebalancing process could be an opportunity for LAC exporters. LAC countries should take advantage of the gap left by China's retreat. However, would the current competitive landscape of LAC exports allow for it? Are there other emerging competitors that might fight for that space in the short and medium run? The purpose of this section is twofold: first, to quantify the competition faced by LAC economies in their export destination markets; ${ }^{14}$ and second, to identify trends and build hypotheses on how these trends may change in the future in lieu of Chin a's rebalancing.

While the literature on Chinese competition in third markets has focused mostly on competition against other Asian markets, there are studies that have also covered other locations, including LAC. The empirical literature has analyzed Chinese competition in third

\footnotetext{
${ }^{14}$ The focus is on LA6 countries: Argentina, Brazil, Chile, Colombia, Mexico and Peru.
} 
markets using a variety of approaches. ${ }^{15}$ The main finding is that South and South-East Asian countries were the most affected by increased Chinese competition, particularly low-income countries whose exports are concentrated in labor-intensive goods (Ahearne et al, 2003; Blázquez-Lidoy et al, 2006; Eichengreen et al, 2007; Greenway et al, 2008; Dimaranan et al, 2009; Bellucci and Hiratuka, 2017). ${ }^{16}$ Regarding LAC, the literature found that China's expansion was a threat for most LAC exporters. (Ianchovichina and Martin, 2006; Lederman et al, 2006; Devlin et al, 2006; Lall and Weiss, 2007; Moreira, 2007; Jenkins and Dussell Peters, 2009; Freund and Özden 2009; Bellucci and Hiratuka, 2017). However, some of these studies found that the negative impact of Chinese competition was limited to only some LAC countries (e.g. Mexico and Central America) and/or sectors (e.g. light manufacturing), as most competition took place in the U.S. market.

\section{B. TRADE COMPETITION INDEX}

With focus on merchandise exports, we analyze the degree of competition faced by LA6 countries from its major competitors across their dominant export products by constructing the value- and the count-based indices of competition proposed by Mattoo et al (2017). For the main competitors and the dominant products, we examine the variation in competition indices across destination markets and time. This approach to quantify competition against LAC countries in third markets positions this paper as part of the literature that is focused on trade indicators analysis mentioned previously.

The value-based index (VBI) of competition captures the degree of competition faced by a given exporter, in a specific destination country, for a certain product. Exposure to competition is measured by the dominance of a competing country in a product market and in a destination country. The analy sis is done at a high level of product aggregation (i.e. the HS four-digit level) to ensure that the range of products exported to a destination country by a given country and its competitors actually overlap..$^{17}$

Country $i$ 's exports to country $j$ of product $g$ are expressed as:

$$
V_{g}^{i j}=\sum_{g^{\prime}=1}^{G} V_{g^{\prime}}^{i j},
$$

\footnotetext{
${ }^{15}$ The methodologies used in the litera ture to quantify the impact of China's tra de expansion on different groups of countries include: (i) trade indicator a naly sis with focus on export structures (Lall and Weiss, 2007; Moreira, 2007) and market shares (Jenkins, 2010; Jenkins and Du ssel Peters, 2009; Husted and Nishioka, 2010; Hiratuka et al,2012); (ii) computable general equilibrium models (Dimaranan et a12009; Ianchovichina et al, 2009); and (iii) the estimation of gra vity models (Eichengreen et al, 2007; Greenaway et al, 2008; Athukorala, 2009; Giovanetti and Sa nfilippo, 2009; Devadason, 2010; Bellucci and Hira tuka, 2017).

${ }^{16}$ Different from these studies, Athukorala (2009) and Devadason (2010), based on the estimation of gra vity models, found evidence that Chinese competition did not crowd out other Asian countries' exports.

${ }^{17} \mathrm{HS}$ is the harmonized sy stem of product cla ssification used in tradedata. Ea ch HS six -digit product can be ma pped to its parent HS four-digit product. Using the same example a s in Mattoo et al (2017), the two six-digit ca tegories, 852810 for "Color Television Receivers" and 852820 for "Black and Whiteor Other Monochrome Television Receivers," map on to the four-digit product 8528 for a ll "Television Receivers."
} 
where $G$ denotes the number of HS six-digit lines within the four-digit product. Following the notation of Mattoo et al (2017), a good at a four-digit level of aggregation is referred to as a "product" and denoted by $g$, whereas a good at a six-digit level of aggregation is referred to as a "six-digit line" and denoted by $g$ '.

The competition faced by country $i$, with respect to competitor $c$, in a destination country $j$, for product $g$, is measured as:

$$
I_{g}^{i, c, j}=\sum_{g^{\prime}=1}^{G}\left(\frac{V_{g}^{i, j}}{g^{\prime}}\right) \times s_{g^{\prime}}^{c, j},
$$

where $s_{g}^{c, j}$ is measured as the value of the six-digit line $g$ ' exports by competitor $c$ to country $j$, divided by the total six-digit line $g$ ' exports to country $j$.

The index includes two elements: (i) the relative importance of competitor $c$, as a source of exports of a six-digit line $g$ ' to country $j, s_{g^{\prime}}^{c, j}$; and (ii) the relative importance of a six-digit line $g^{\prime}$ in the exports of country $i$ to destination country $j, V_{g^{\prime}}^{i j} /\left[\sum_{g^{\prime}} V_{g^{\prime}}^{i j}\right]$. The product of the two terms obtained at the HS six-digit level is then aggregated to obtain the VBI at the HS fourdigit level.

To better understand the construction of the VBI, consider the following example taken from Mattoo et al (2017). If the HS four-digit product, TVs, consists of only two items, color TVs and non-color TVs, the VBI of competition is simply the weighted sum of the share of imports from competitor $c$ in country $j$ 's total imports of each type of TV, where the weight is the importance of each type of TV in country $j$ 's TV imports from country $i$.

By taking into account the value of exports to country $j$, the VBI captures the intensive margin of competition. Alternatively, a count-based index (CBI) of competition captures the extensive margin of competition, i.e. number of products exported by a competitor that are also exported by the country under consideration, regardless of their value. The CBI is given by:

$$
\bar{I}_{g}^{i, c, j}=\frac{N_{g}^{i, c, j}}{N_{g}^{i, j}} .
$$

It measures the number of six-digit lines (within a four-digit product) that are exported to destination country $j$ by both competitor $c$ and country $i$, as a proportion of the total number of six-digit lines (within that four-digit product) exported to destination country $j$ by country $i$. 


\section{DATA}

To construct the VBI and CBI, we use the bilateral merchandise trade data at HS-6-digit level of product disaggregation from the BACI World Trade Database, provided by CEPII. ${ }^{18}$ The original data behind BACI are the UN COMTRADE data. The index has been measured at two snapshots over time, 2000 and 2015.

To identify the set of important competitors for a given country, we consider products at the HS-4-digit level whose share in total exports was up to 51 percent in $2015 .{ }^{19}$ The number of products which fulfills this criterion ranges from 2 for Colombia to 12 for Brazil and Mexico, depending on the degree of concentration of exports. Then, for each product, we determined the top ten exporters by value. These exporters yielded the relevant set of competitors for a given country, which ranges from 18 competitors for Colombia to 52 competitors for Brazil. ${ }^{20}$

\section{RESULTS}

\section{i. Main Competitors}

To compute the VBI at the competitor level, we average the VBI across all products and destination markets for each competitor. This yields an estimate of the average VBI for each LA6 country with respect to each competitor. The same procedure is followed for the CBI. The results based on VBI for 2015 are reported in Figure 17, and those based on CBI in the Appendix (Figure II.1).

For value-based competition, the U.S. and China are by far the most dominant competitors in 2015 (Figure 17, Panel A). Some advanced economies play important roles as competitors for LAC countries, though to a much lesser extent than the U.S. and China (Figure 17, Panel B). For instance, Germany is among the top three competitors for all LA6 countries except Colombia, followed by some other European economies, including Italy, France, Spain and Netherlands. In the case of Colombia, the competition with North America (including Canada) is the strongest, and there is barely no competition with Europe. Moreover, Japan and South Korea are within the top 10 competitors for most LA6 countries.

As shown in Figure 17 (Panel C), among emerging markets, China is the top competitor for Mexico, Brazil, Argentina and Colombia, explained by the fact that these are the most industrialized LA6 countries. In the case of Peru and Chile, China is not a significant competitor because of the product space in which these countries compete, mostly minerals. Similar results are obtained using the count-based index.

\footnotetext{
18 The data used to construct the index of competition is available at: http://www.cepii.fr/CEPII/en/bdd_modele/bdd_modele.asp

${ }^{19}$ See Table II. 1 for a list of the relevant products for each country.

${ }^{20}$ See Table II. 2 for a list of competitors for each country.
} 
There are other emerging economies in Asia, beyond China, that compete against LA6 countries for the same markets, though from far behind. For instance, India is the second largest competitor for Brazil and Colombia among emerging markets, and the third for Chile and Peru. Indonesia and Thailand are also smaller competitors, though still within the top 10 among emerging markets.

There is some degree of competition within LA6 as well. Brazil and Argentina compete with Mexico (third largest competitor among emerging economies for both countries), and among themselves. Argentina also competes with Uruguay and Bolivia, while Brazil with Colombia and Chile. Meanwhile, Brazil and Mexico are the top two competitors for Chile and Peru. Also, Chile and Peru compete among themselves.

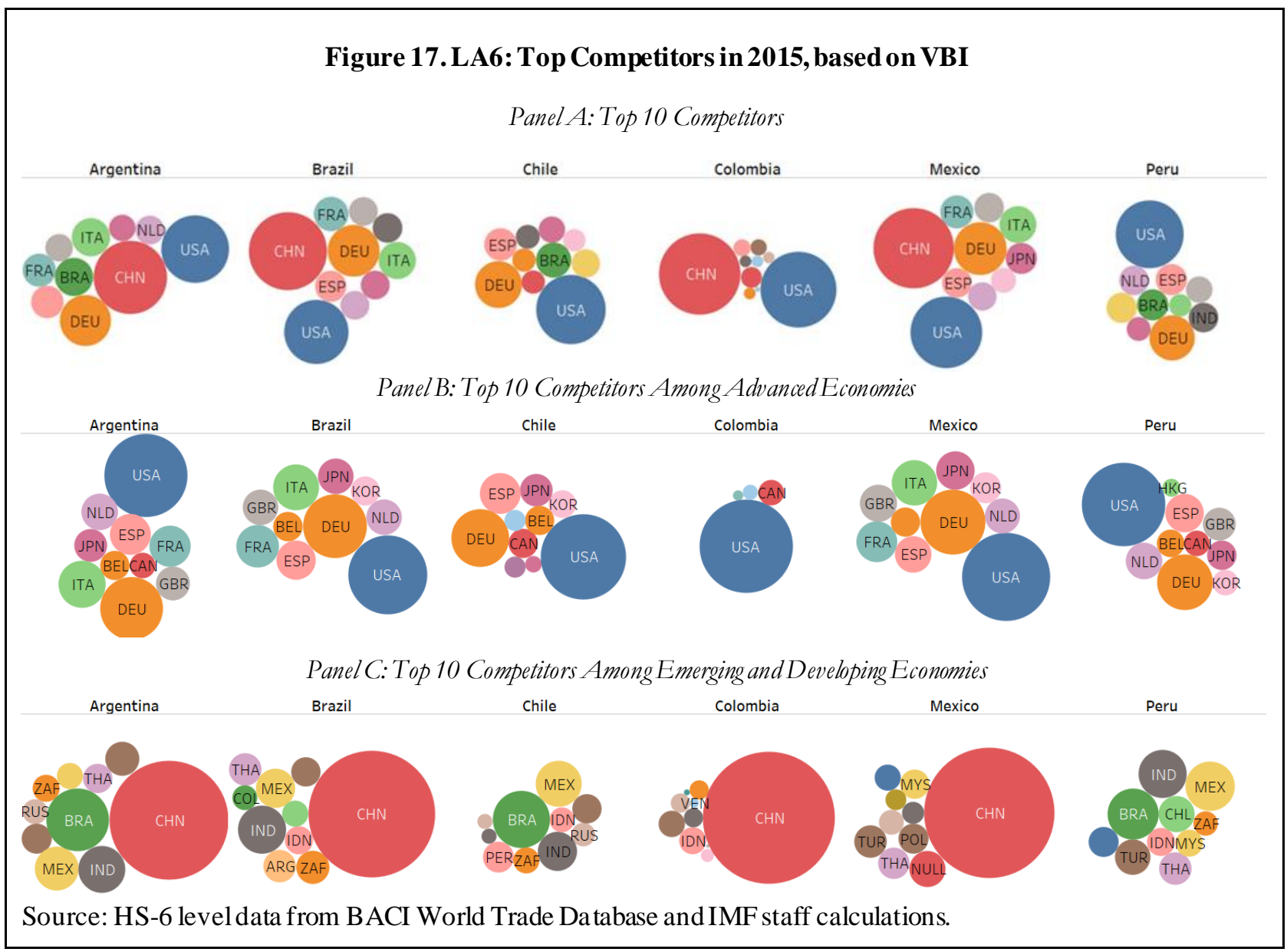

The competition from China has increased over time, at the expense of advanced economies, particularly the U.S., which is reflected in China's high share in imports and exports, as shown in Section II. Figure 18 compares the VBI for each LA6 country with respect to each of its top 10 competitors in 2000 and 2015. We produce the same graph for the CBI and report it in the Appendix (Figure II.2). For most countries, count-based competition remained relatively stable or even increased over time. However, value-based competition 
from China significantly increased, at the expense of advanced economies, particularly the U.S., from whom the competition has declined. This trend is particularly noticeable in Mexico, Brazil, Argentina and Colombia.

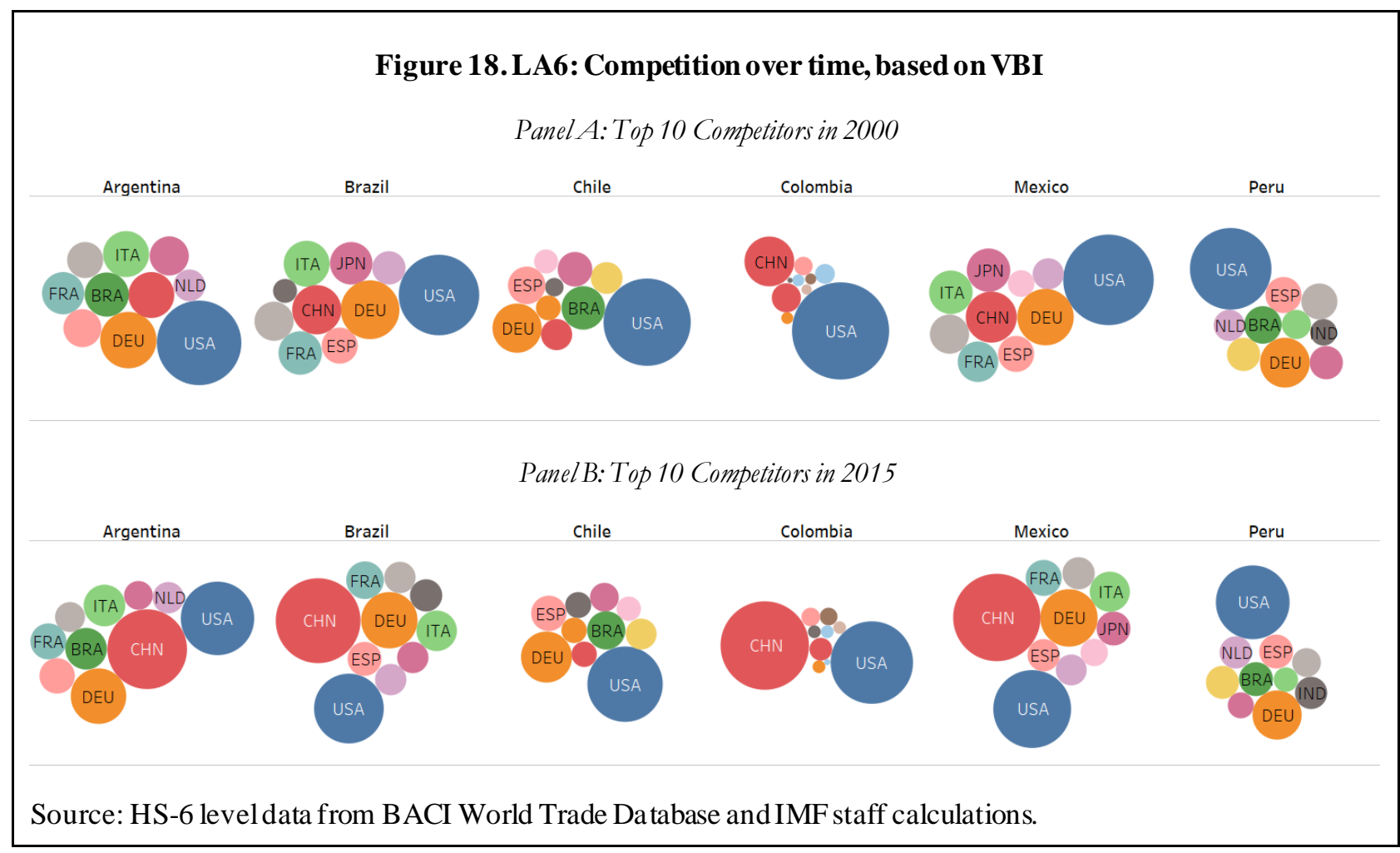

By focusing on the top 10 competitors, Figure 18 does not reflect the growing importance of smaller competitors. This is shown in Figure 19. Each chart displays a scatterplot of the VBI in 2000 and the VBI in 2015. For a given LA6 country, if a competitor is located below the 45-degree line it means that competition against that country increased between 2000 and 2015. The points highlighted in orange correspond to competitors that displayed the largest increases in competition. Given that the focus is on smaller competitors, and for the sake of visibility, U.S., China and Germany were excluded from the graphs.

Competition from emerging and developing has increased, not only from China, but also from other countries, especially India. For instance, competition of India has increased for all LA6 countries except Colombia and Mexico. In the case of Argentina, it seems that India is taking the space left by other LA6 countries, such as Brazil, from whom the competition has declined. In the case of Chile, competition with other LA6 countries (Brazil, Mexico and Peru) has also declined, paving the way to other competitors such as India and Poland. A similar pattern is observed in Peru, but the group of rising competitors is India, Turkey, Vietnam and Malaysia. In the future, China's rebalancing coupled with continued growth by India may lead to a consolidation of the latter as a strong competitor for LA6 countries. 
Figure 19. LA6: Competition over time, based on VBI
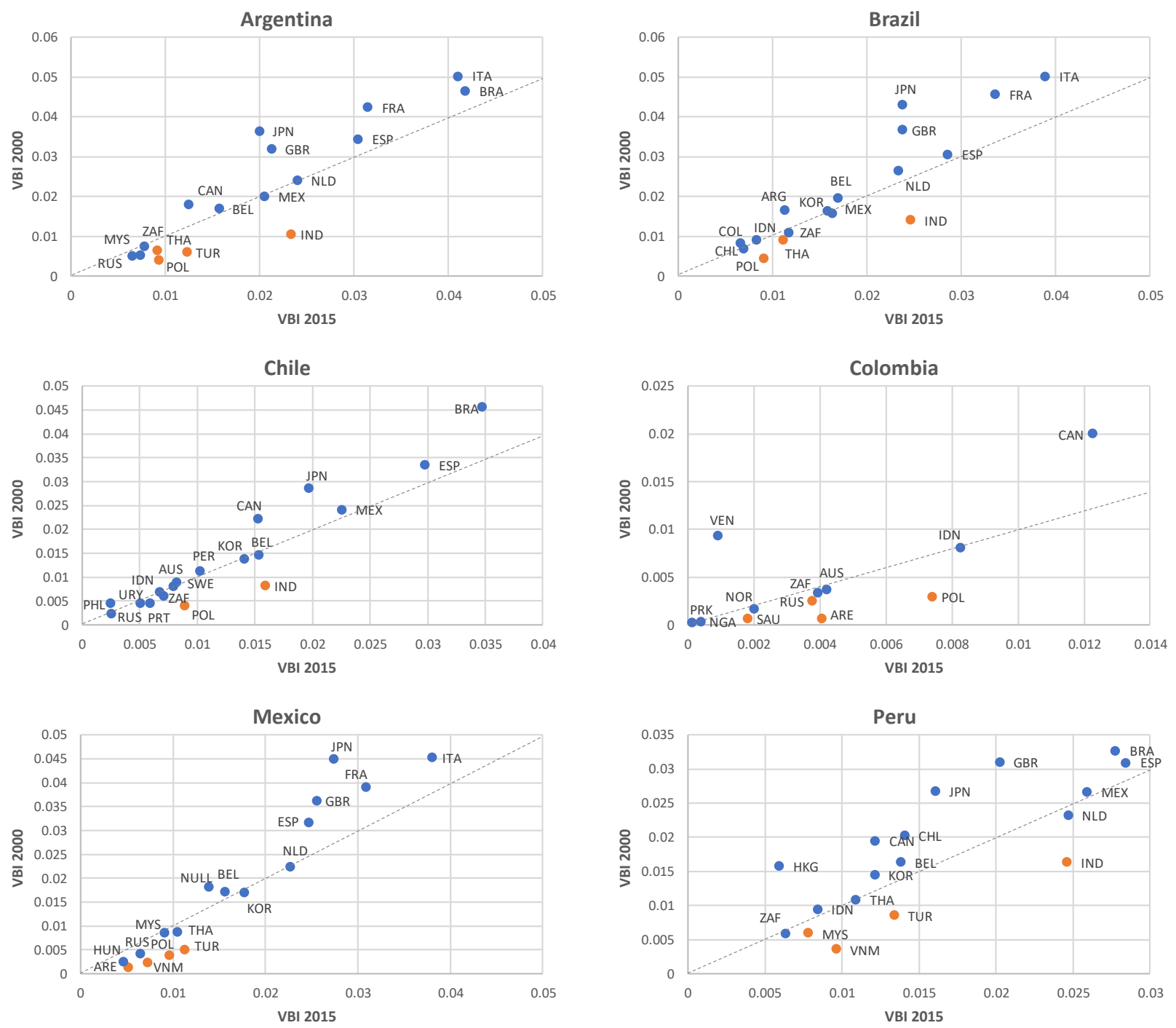

Source: HS-6 level data from BACI World Trade Da tabase and IMF staff calculations.

Note: The dotted line represents the 45-degree line. For a given LA6 country, if a competitor is loca ted below the 45degree line it means that competition has increased between 2000 and 2015. The points highlighted in ora nge correspond to the competitors that displayed the largest increases in competition. U.S., China and Germany were excluded from the graphs for the sake of visibility. 


\section{ii. Competition in the Product Space}

LA6 countries tend to face more competition in manufacturing products and some specific commodities, such as gold and petroleum. To arrive at a product-level VBI and CBI, we average across all destination countries and competitors for each HS4 product line. We restrict the analysis to the major export products, which are picked based on their export shares. Given that these products are the major exports of each country, they are likely to be the products in which these countries have a comparative advantage. Figure 20 shows, for each LA6 country, the VBI of the top 10 products (by export share), in a decreasing order of export share as we go from left to right. Together, these products account for up to 51 percent of merchandise exports in 2015. The equivalent graph for CBI is shown in the Appendix (Figure II.4).

The fiercest competition occurs in manufacturing products. This is the case for most products in Mexico, for motor vehicles in Brazil and Argentina, for aircrafts in Brazil, and for wood pulp/soda/sulphate in Brazil and Chile.

Competition in commodities is high for some products and low for others. For instance, Colombia faces low competition in coffee, flowers and bananas. ${ }^{21}$ Both Colombia and Brazil face relatively lower competition in cane sugar, and Chile in fish, grapes, and wine from fresh grapes. Peru faces low competition in petroleum gases. However, for other commodities such as petroleum, coal, and gold, the competition is stronger. This is the case of Colombia and Peru. In addition, Chile and Peru compete among themselves in copper, and Argentina and Brazil in soya.

When comparing VBI against CBI, CBI competition tends to be higher than VBI competition across all export products. This could be evidence that, even though these product lines are highly contested, varieties exported by LA6 may be of a higher quality. In other words, competitors are selling many common HS-6-digit products in the same markets, but the value of these products tends to be lower, which may indicate lower quality.

We also analyze the evolution of the VBI index for the top products over time. Competition against Argentina has increased in several commodity categories, including wheat, petroleum and gold. In the case of Brazil, competition in product markets has remained relatively stable, except for cane sugar, chemical wood pulp/soda/sulphate and petroleum where the index shows a small decline. Something similar has occurred in Mexico, with stable competition in most product categories, except for petroleum and transmission apparatus, which have increased over the past five years. While competition in Colombia has increased in petroleum, it has decreased in gold, with no major changes in the other product markets. Competition against Chile has declined in fish, gold and unrefined copper, while it has increased in copper ores and refined copper. Finally, in the case of Peru, competition in the

\footnotetext{
${ }^{21}$ However, while low for Colombia, competition in coffee is high for Peru. This might be linked to production of different coffee varieties.
} 
past five years has increased in most product categories, except coffee, molybdenum ores and gold. The results based on CBI are broadly in line with those based on VBI. ${ }^{22}$

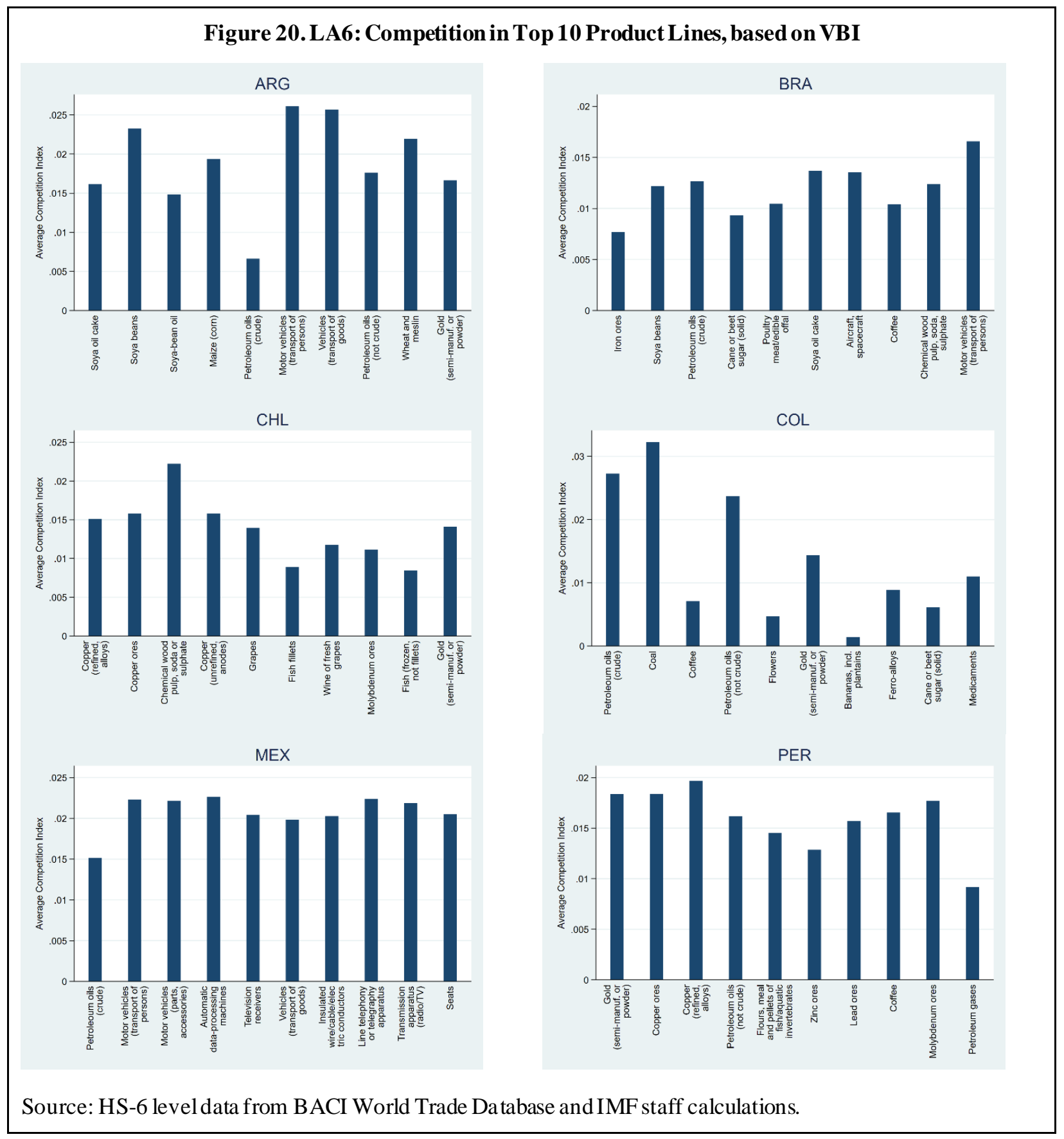

${ }^{22}$ The differences in CBI competition, rela tive to VBI competition, a re: (i)Colombia in the gold market has seen increa sed CBI competition in the la st five years; (ii) increa sed CBI competition a gainst Brazil in the markets of coffee and motor vehicles; (iii) higher CBI competition faced by Mexico in petroleum, and lower in motor vehicles, while the remaining product categories show slight increases. 


\section{REAPING THE BENEFITS OF CHINA'S REBALANCING}

\section{A. DEEPER INTEGRATION}

LAC could benefit from further integration, both within the region and with the rest of the world. High geographical and product concentration, together with weak participation in global value chains, prevents the region from reaching the critical threshold of connectivity needed to play a more central role in the world trade networks (Beaton et al, 2017).

Although LAC tariffs and no-tariff barriers have been declining after World War II following deeper global integration, LAC countries still report higher levels of trade barriers compared to both ASEAN and OECD countries (Figure 21). In particular, the LAC region displays a lower level of international trade openness compared to the OECD, but a similar level of overall trade openness with ASEAN countries. However, the overall index of openness (freedom to trade internationally) masks some heterogeneity with respect to the individual components of the index. LAC countries still lag ASEAN countries with respect to tariffs and non-tariff barriers, but they score better than ASEAN with respect to capital controls and free movement of capital and people.

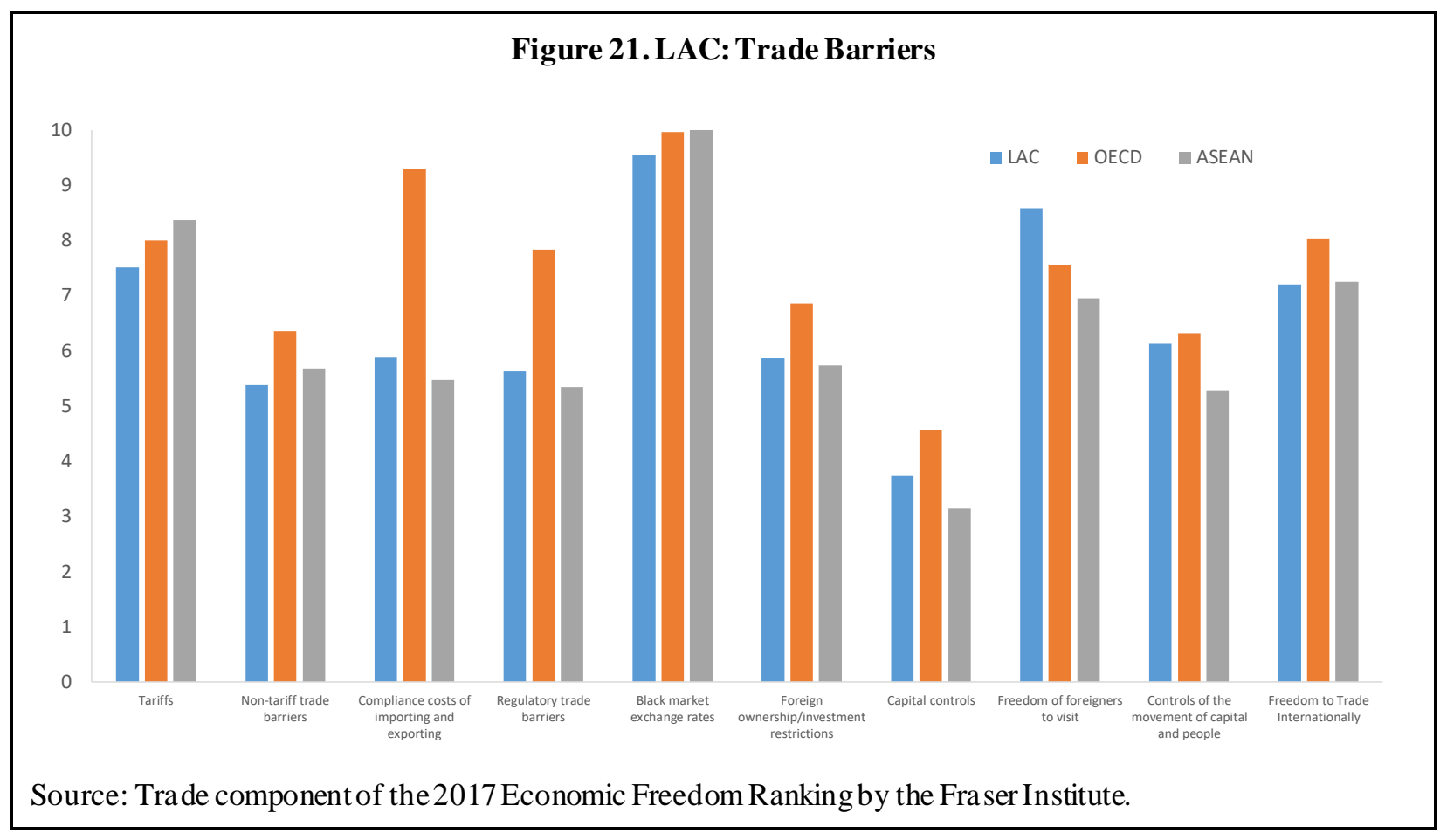

Non-tariff measures are important constraints to LAC exporting. LAC export is often constrained by regulatory standards, such as sanitary and phytosanitary standards (SPS) and technical barriers to trade (TBT), including labeling, technical specifications and quality assurances (Mowatt, 2017). SPS and TBT are considered the most common non-tariff measures, covering between 15 and 30 percent of trade respectively (UNCTAD, 2013). 
Investment in new technology, more efficient trade infrastructure, and the use of more advanced shipping methods could help mitigate the impact of such restrictions. Moreover, promoting consolidation in the exporting sector could help reduce the impact of these fixed costs on firms' profitability and make LAC export more competitive at global level. More integration would allow the region to better respond to shocks, particularly to China's rebalancing. In this section we use the model developed in Section III to study the impact of increased integration in LAC in the context of China's rebalancing.

\section{i. Scenario Definition}

We quantify the impact of two scenarios. In the first scenario, LAC unilaterally liberalizes trade in goods and services within the region. In the second scenario, LAC unilaterally liberalizes trade in goods and services with the rest of the world. Liberalization in goods involves setting the tariffs of goods to zero. Liberalization in services implies a reduction in non-tariff barriers by 10 percent.

All scenarios assume that trade liberalization occurs after the China rebalancing shock materializes. Therefore, the scenarios will be analyzed by looking at the effects of China's rebalancing with and without trade liberalization. The baseline scenario uses the configuration of tariffs in effect at end-2015.

\section{ii. Effect of LAC's trade liberalization in the context of China's rebalancing}

Following LAC's trade liberalization, overall world trade expands, and LAC exports rise (Figure 22). In the full liberalization scenario, world trade of goods increases by 2 percent, and world trade in services increases by 15 percent. Similarly, LAC exports of goods and of services rise by 3 percent and 7 percent, respectively. Most of the effect is coming from larger trade flows of goods within LAC and increased trade in services between LAC and the rest of the world (particularly China). The effects of liberalization within LAC are also positive, but quantitatively smaller, and mostly affecting goods trade. Liberalizing trade in services within the region does not seem to have significant effects, partly because exports of services are still relatively small as a share of total exports.

Even a scenario of modest trade liberalization by LAC more than makes up for the negative effect from China's rebalancing. As shown in Figure 23, real GDP of all LAC countries would increase as a result of liberalization. Overall, real GDP in LAC would increase by 0.4 percent with goods and services liberalization within the region, and by 1.2 percent with full liberalization. Exports of goods and services would increase as well for all countries. 
Figure 22. Impact on trade of LAC's liberalization
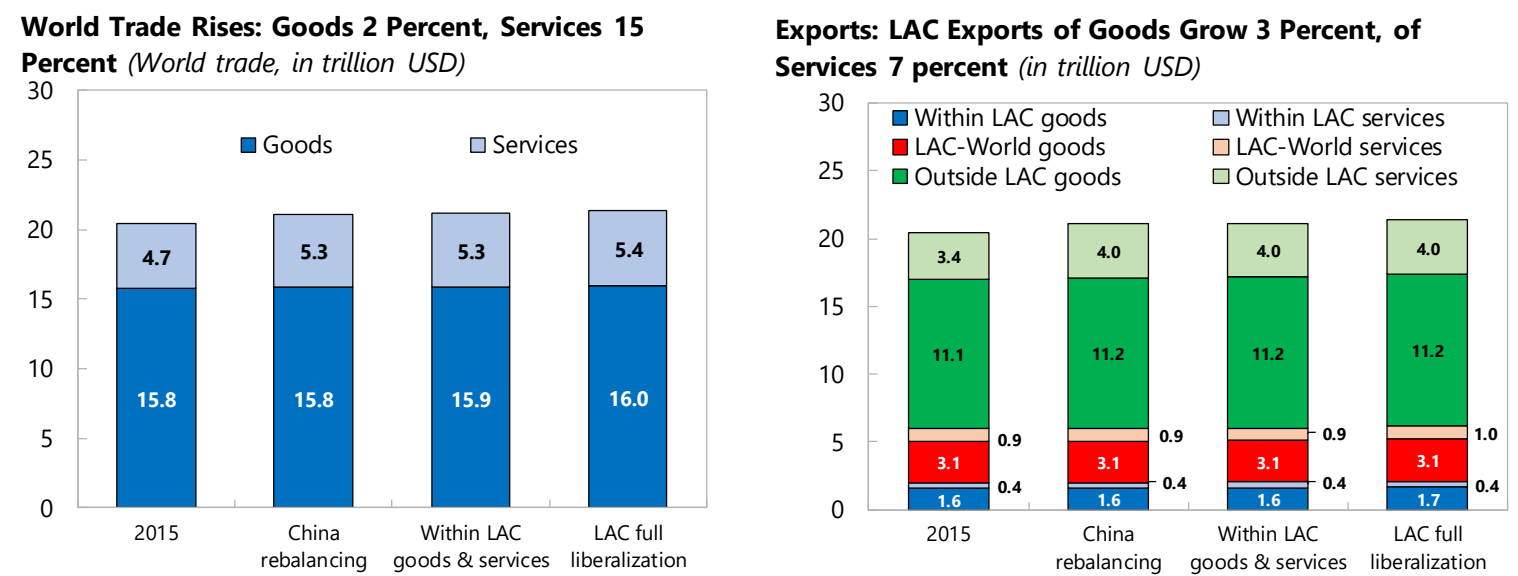

Source: IMF staff calculations. The figures show theeffects of liberalization (under the different scenarios) after the combined shock, and using the U.S. a s benchmark.

Figure 23. Impact of LAC's liberalization by country

Panel A. Real GDP

\section{Changes in Aggregate Real GDP Across \\ Scenarios}

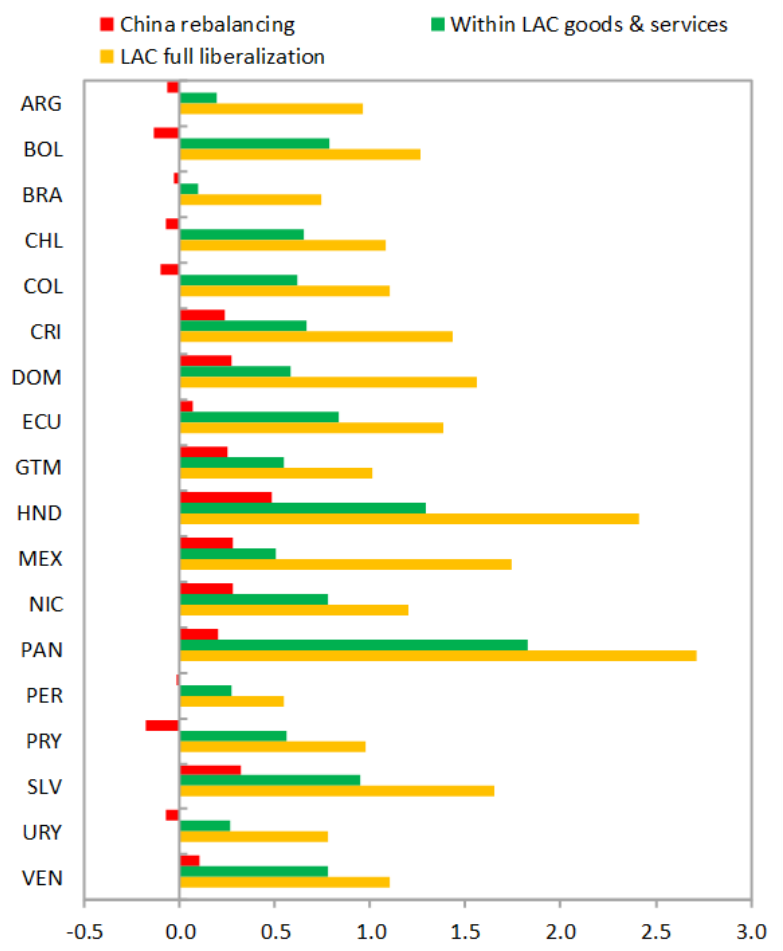

Source: Authors' calculations.
Panel B. Real exports

\section{Changes in Aggregate Real Exports Across Scenarios}

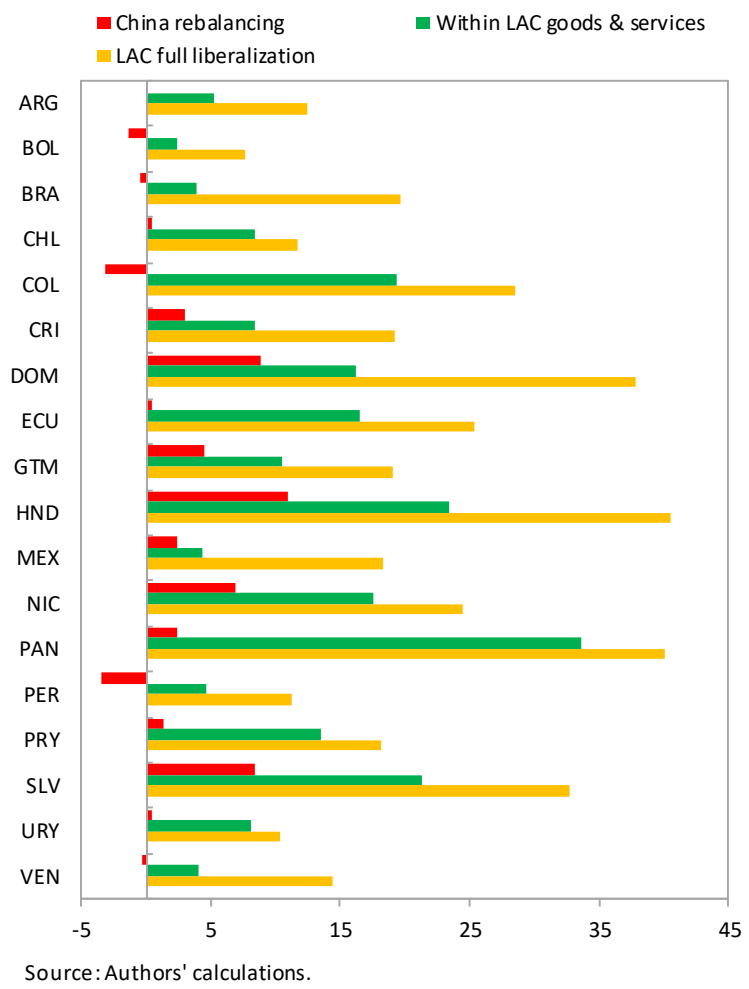

Source: IMF staff calculations. The figures show theeffects of liberalization (under the different scenarios) after the combined shock, and using the U.S. a s benchmark. 
Full liberalization is associated with an increase in both real GDP and exports in LAC, that offset the negative impact of China's rebalancing. As shown in Figures 24 and 25, and as discussed previously, the overall effect of China's rebalancing on LAC countries is marginally positive both in terms of GDP and exports but uneven, featuring winners and losers. Full trade liberalization would inequivocally make all LAC countries better off. The reduction in trade barriers would increase LAC exports, particularly of services, and utimately their GDP.

\section{B. OTHER POLICIES}

Beyond regional integration and the removal of trade barriers, LAC countries should adopt additional policy measures to maximize the potential benefits of China's rebalancing on their exports. Further impediments to LAC export potential include supply side constraints, such as low levels of human capital, poor trade-related infrastructure, and underdeveloped industrial technology.

More efforts are needed in LAC to close sizeable infrastructure gaps and improve the provision of basic services, including electricity, water and sanitation, and transportation. Ongoing FDI in the utilities sector, including from China, is already providing support in this direction. China's rebalancing, and in particular its efforts to export excess capacity and enhance comparative advantage, could lead to further increases of China's FDI in LAC (Ding et al, 2020).

Boosting productivity will require improving the quality of labor through stronger and more efficient investment in education and health. In addition, the case of Costa Rica has shown that attracting export-oriented foreign firms in high-tech and knowledge sectors, including through the establishment of Free Trade Zones, could also increase productivity.

Finally, good macroeconomic policies aiming at stabilizing the economy, including through reductions in exchange rate volatility, would further support the exporting sector in LAC. 
Figure 24. Effect of China's rebalancing on real GDP with/without LAC's liberalization Panel A. China's rebalancing

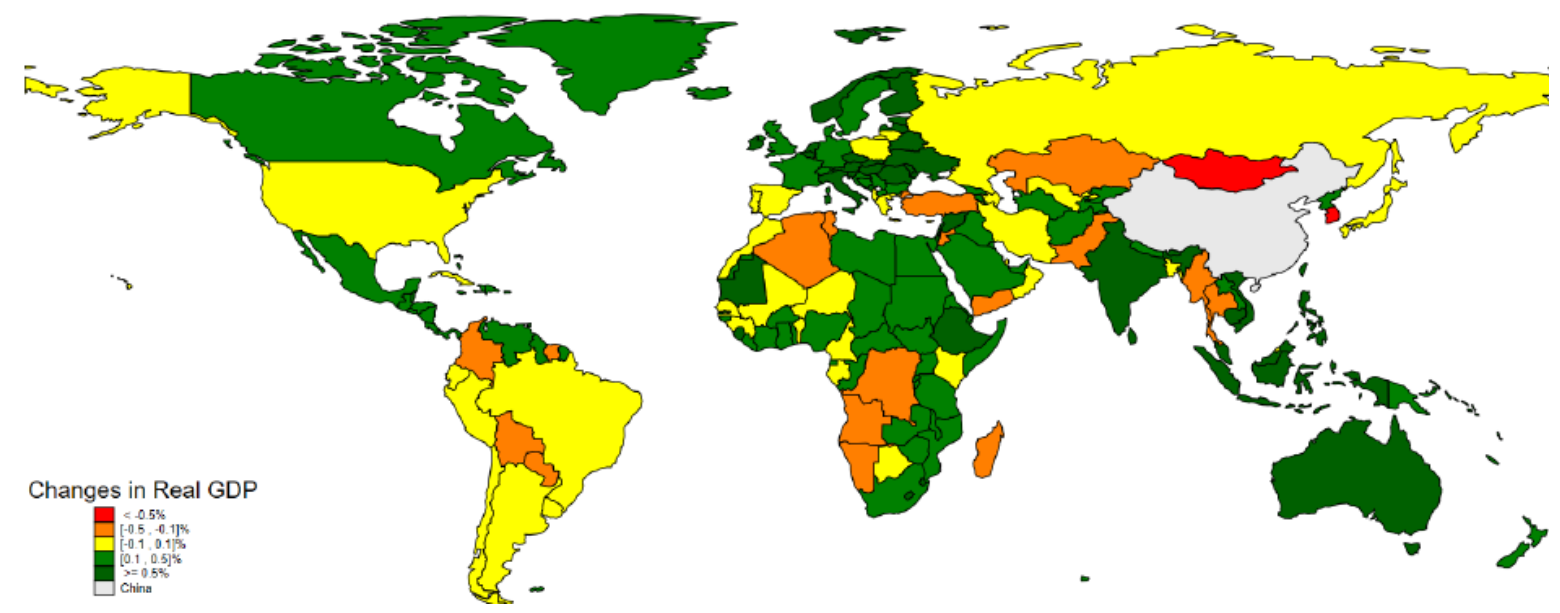

Panel B. China's rebalancing $+L A C$ 's full liberalization

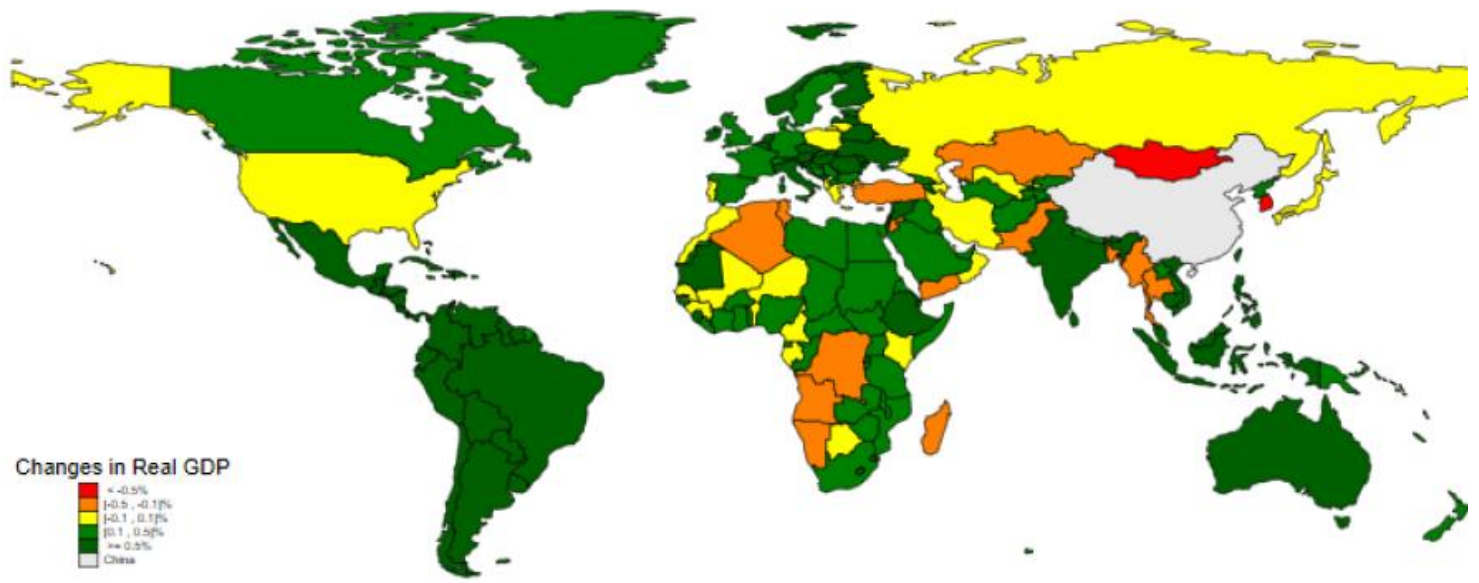

Source: IMF staff calculations. The figures show theeffect of the combined shock using the U.S. as a benchmark, with and without LAC's full libera liza tion. Pa nel A in this figure reports the same information as Panel A in Figure 6; the differences in coloring a re explained by the use of a different scale. The coloring of Figure 6 is ba sed on deciles, while the coloring in this figure is base on fixed value ra nges for a better comparison with the libera lization scenario. 
Figure 25. Effect of China's rebalancing on real exports with/without LAC's liberalization

Panel A. China's rebalancing

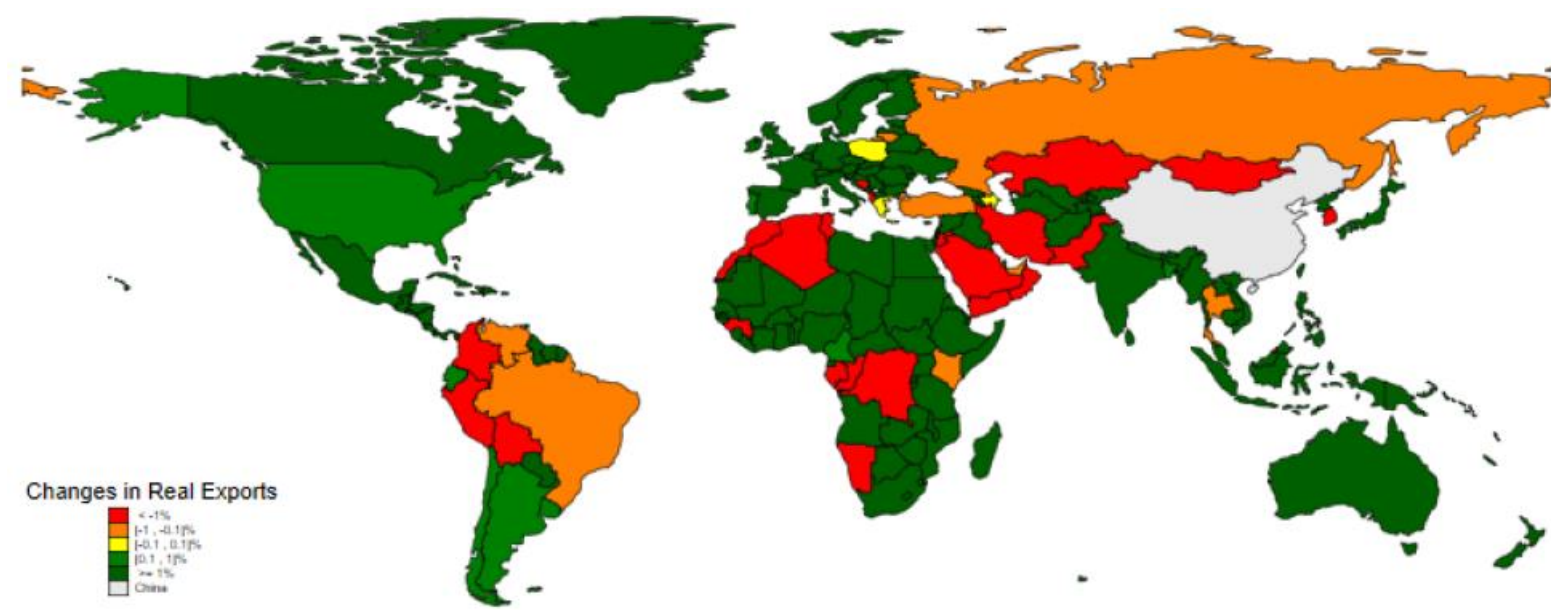

Panel B. China's rebalancing $+L A C$ 's full liberalization

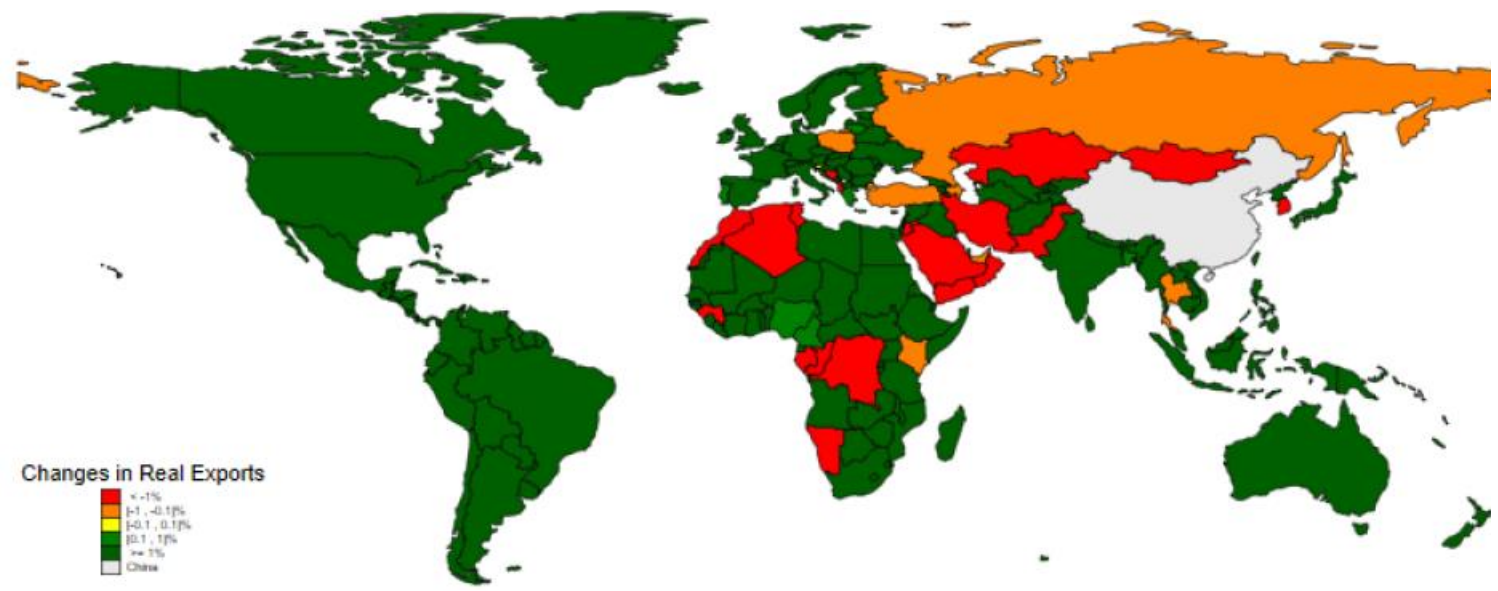

Source: IMF staff calculations. The figures show theeffect of the combined shock using the U.S. as a benchmark, with and without LAC's full liberalization. Panel A in this figure reports the same information as PanelB in Figure 6; the differences in coloring are explained by the use of a different scale. The coloring of Figure 6 is based on deciles, while the coloring in this figure is base on fixed value ranges for a better comparison with the libera lization scenario. 


\section{THE AMPLIFYING EFFECT OF THE COVID-19 PANDEMIC}

The previous sections outline structural changes resulting from China's rebalancing, which were identified before the COVID-19 outbreak. How will the pandemic affect these prospective impacts? While any prediction remains speculative at this point due to the uncertainty surrounding the pandemic, we hypothesize that the COVID-19 shock will exacerbate the effects identified in our analysis. Countries that were already expected to benefit from China's rebalancing, will likely do even better. And those countries that were set to lose, will do even worse. The pandemic will amplify the gap between winners and losers from China's rebalancing.

There are at least two channels in which the COVID-19 crisis will amplify the effects of China's rebalancing.

\section{Diversification of global value chains}

The COVID-19 pandemic has disrupted supply chains around the world. It exposed the vulnerabilities and risks associated with globalized but undiversified supply chains, which were highly concentrated in China and built on the premise of cost minimization. In this environment, firms are considering alternative ways of building resilient and more flexible supply chains, including by shifting production back home or, at least, somewhere close by.

By pushing countries to establish manufacturing production at nearby locations to diversify their supply base, this regionalization trend might intensify the effects of China's rebalancing, further benefitting the winners. Countries that stand to gain the most are those that, given their production structure and comparative advantage, were already set to fill the gap left by China. But not all of them would succeed, as they would need to compete among themselves to win those markets. The pandemic brings an additional element to consider in this competition: geographical location. If a country that was already benefiting from the rebalancing in terms of its comparative advantage, also has a strategic location close to one of the main production hubs (US, Germany, Japan/Korea), then, in a post-COVID era, it will benefit from both the rebalancing and the regionalization, thus boosting its gains.

\section{Decline in services involving high degree of person-to-person interaction}

The lockdowns and voluntary isolation that emerged in the fight against the pandemic have put a toll on the services sectors that involve high degree of person-to-person interaction, such as hospitality, brick and mortar retail or personal grooming services. The aftermath of the COVID-19 crisis may bring a permanent reduction in the demand for these services. If that is the case, the pandemic will negatively affect those countries that will be forced to reallocate into services. Not only they will face China's stronger competition as it rebalances towards services, but they will also face lower demand. Resource-rich countries, which would shift to services due to the rebalancing, may end up in an even worse situation than the one depicted in our pre-COVID predictions. 
However, services that are provided remotely could see much higher demand. Some countries in LAC were already taking steps towards developing online capabilities before the COVID-19 outbreak. This effort will put them in a better position to face the post-pandemic era. For example, consider the outsourcing of professional services to Central America and the Caribbean. In the future, we may see a strong growth in online services as people limit face-to-face interactions. This could be an opportunity for these countries, that can partly compensate a possibly permanent decline in tourism.

\section{CONCLUSIONS}

Over the past 20 years, Asia and LAC have become increasingly connected through international trade, and China has emerged not only as an important trading partner, but also as one of the top competitors of LAC exports. Competition with China has grown substantially. However, China's rebalancing may lead to a retreat from certain markets, giving LAC countries the opportunity to fill that gap.

But LAC is not alone in this race. There are also other countries, such as India, that are trying to fill that gap as well, and there is already evidence of increasing competition by these emerging economies in LAC's export markets.

What can LAC countries do in response to this increased competition? There are several possible lines of action:

(i) Deepen regional integration;

(ii) Improve infrastructure (including information and communications technology), and reduce logistics costs;

(iii) Improve the quality of products that face the strongest competition. 


\section{REFERENCES}

Ahearne, A., Fernald, J., Loungani, P., \& Schindler, J. (2003). China and emerging Asia: comrades or competitors? International Finance Discussion Papers 789. Board of Governors of the Federal Reserve System (U.S.).

Ahuja, A., \& Myrvoda, A. (2012). The Spillover Effects of a Downturn in China's Real Estate Investment. IMF Working Paper WP/12/226. International Monetary Fund.

Ahuja, A., \& Nabar, M. (2012). Investment-Led Growth in China: Global Spillovers. IMF Working Paper WP/12/267. International Monetary Fund.

Anderson, D., Canales Kriljenko, J. I., Drummond, P., Espaillat, P., \& Muir, D. (2015). The Flexible System of Global Models - FSGM. IMF Working Paper WP/15/64. International Monetary Fund.

Athukorala, P. C. (2009). The rise of China and East Asian export performance: is the crowding out fear warranted? World Economy, 32, 234-266.

Bellucci Módolo, D., \& Hiratuka, C. (2017). The impact of Chinese competition on third markets: an analysis by region and technological category. Development Policy Review, 35, 797-821.

Blázquez-Lidoy, J., Rodríguez, J., \& Santiso, J. (2006). Angel or devil? China's trade impact on Latin American emerging markets. OECD Development Centre Working Papers 252. OECD Publishing.

Caceres, C., Cerdeiro, D. A., \& Mano, R. (2019). Trade Wars and Trade Deals: Estimated Effects using a Multi-Sector Model. IMF Working Paper WP/19/143. International Monetary Fund.

Caliendo, L., \& Parro, F. (2015). Estimates of the Trade and Welfare Effects of NAFTA. Review of Economic Studies, 82(1), 1-44.

Caliendo, L., Feenstra, R. C., Romalis, J., \& Taylor, A. M. (2017). TariffReductions, Entry, and Welfare: Theory and Evidence for the Last Two Decades. NBER Working Paper 21768. National Bureau of Economic Research, Inc.

Casanova, C., Xia, L., \& Ferreira, R. (2016). Measuring Latin America's export dependency on China. Journal of Chinese Economic and Foreign Trade Studies, 9, 213-233.

Cashin, P., Mohaddes, K., \& Raissi, M. (2016). China's Slowdown and Global Financial Market Volatility: Is World Growth Losing Out? IMF Working Paper WP/16/63, International Monetary Fund.

Costinot, A., \& Rodriguez-Clare, A. (2014). Trade Theory with Numbers: Quantifying the Consequences of Globalization. Handbook of International Economics, 4, 197-261.

Devadason, E. (2010). ASEAN-China and trade flows: moving forward with ACFTA. Journal of Contemporary China, 19, 653-674.

Devlin, R., Estevadeordal, A., \& Rodríguez-Clare, A. (Eds.). (2006). The emergence of China: opportunities and challenges for Latin America. Washington, D.C. and Cambridge, MA: Interamerican Development Bank and David Rockefeller Center for Latin American Studies, Harvard University.

Di Giovanni, J., Levchanko, A. A., \& Zhang, J. (2014). The Global Welfare Impact of China: Trade Integration and Technological Change. American Economic Journal: Macroeconomics, 6(3), 153-183.

Dimaranan, B., Ianchovichina, E., \& Martin, W. (2009). How will growth in China and India affect the world economy. Review of World Economics, 145, 551-571. 
Ding, D., Di Vittorio, F., Lariau, A., \& Zhou, Y. (2020). Chinese FDI in LAC: One Man's Excess Capacity is Another Man's Treasure? International Monetary Fund.

Dizioli, A., Guajardo, J., Klyuev, V., Mano, R., \& Raissi, M. (2016). Spillovers From China's Growth Slowdown and Rebalancing to the ASEAN-5 Economies. IMF Working Paper WP/16/170. International Monetary Fund.

Eaton, J., \& Kortum, S. (2002). Technology, Geography and Trade. Econometrica, 70(5), 1741-1779.

Eaton, J., Kortum, S., Neiman, B., \& Romalis, J. (2016). Trade and the Global Recession. American Economic Review, 106(11), 3401-3438.

Eichengreen, B., Rhee, Y., \& Tong, H. (2007). China and the exports of other Asian countries. Review of World Economics, 143, 201-226.

Freund, C., \& Özden, C. (2009). The effect of China's exports on Latin American trade with the world. In D. Lederman, M. Olarreaga, \& G. Perry (Eds.), China's and India's challenge to Latin America: opportunity or threat (pp. 179-215). Washington, D.C.: World Bank.

Giovanetti, G., \& Sanfilippo, M. (2009). Do Chinese exports crowd-out African goods? An econometric analysis by country and sector. European Journal of Development Research, 21, 506-530.

Greenaway, D., Mahabir, A., \& Milner, C. (2008). Has China displaced other Asian countries' exports? China Economic Review, 19, 152-169.

Hiratuka, C., Castilho, M., Módolo, D. B., Cunha, S. F., \& Sarmiento, K. (2012). Avaliação da competição Chinesa em terceiros mercados. In G. Bittencourt (Ed.), El impacto de China en America Latina: Comercio e Inversiones (pp. 135-192). Montevideo: Red Mercosur.

Hong, G. H., Lee, J., Liao, W., \& Seneviratne, D. (2016). China and Asia in Global Trade Slowdown. IMF Working Paper WP/16/105. International Monetary Fund.

Hsieh, C. T., \& Ossa, R. (2016). A Global View of Productivity Growth in China. Journal of International Economics, $102(\mathrm{C}), 209-224$.

Husted, S., \& Nishioka, S. (2010). The rise of Chinese exports. Working Paper 391, University of Pittsburgh.

Ianchovichina, E., \& Martin, W. (2006). Trade impacts of China's WTO accession. Asian Economic Policy Review, 1, 45-65.

Ianchovichina, E., Ivanic, M., \& Martin, W. (2009). Implications of the growth of China and India for the other Asian giant: Russia. Policy Research Working Paper, WPS 5075. Washington, D.C.: World Bank.

International Monetary Fund. (2010). Regional Economic Outlook: Asia and the Pacific. Washington DC, April.

International Monetary Fund. (2011). People's Republic of China: Spillover Report for the 2011 Article IV Consultation and Selected Issues. IMF Country Report, 11/193.

International Monetary Fund. (2014). IMF Multilateral Policy Issues Report: 2014 Spillover Report. Washington DC, June.

International Monetary Fund. (2016a). Regional Economic Outlook: Asia and the Pacific. Washington DC, May.

International Monetary Fund. (2016b). The Growing Importance of Financial Spillovers from Emerging Market Economies. IMF Global Financial Stability Report. Washington DC, April. 
International Monetary Fund. (2018). External Sector Report. Washington DC, July. International Monetary Fund. (2019). World Economic Outlook. Washington DC, April. Jenkins, R. (2010). China's global growth and Latin American exports. In A. U. SantosPaulino, \& G. Wan (Eds.), The Rise of China and India. Studies in Development Economics and Policy (pp. 220-240). London: Palgrave Macmillan.

Jenkins, R., \& Dussel Peters, E. (Eds.). (2009). China and Latin America: economic relations in the twenty first century. . Bonn: German Development Institute.

Kahn, T., Molina, D., Ramizo, D., Pesadilla, G., Burmeister, L., Mesquita Moreira, M., \& Wignaraja, G. (2012). Shaping the Future of the Asia-Latin America and the Caribbean Relationship. Washington, D.C.: Inter-American Development Bank.

Kireyev, A., \& Leonidov, A. (2016). China's Imports Slowdown: Spillovers, Spillins and Spillbacks. IMF Working Paper WP/16/51. International Monetary Fund.

Lall, S., \& Weiss, J. (2007). China and Latin America: Trade Competition 1990-2002. In J. Santiso (Ed.), The visible hand of China in Latin America (pp. 85-107). Paris: OECD Publishing.

Lederman, D., Olarreaga, M., \& Perry, G. (2006). Latin America and the Caribbean response to the growth of China and India: overview of research findings and policy implications. Working Paper 66654. Washington, D.C.: World Bank.

Lenzen, M., Moran, D., Kanemoto, K., \& Geschke, A. (2013). Building EORA: A Global Multi-Region Input-Output Database at High Country and Sector Resolution. Economic Systems Research, 25(1), 20-41.

Mano, R. (2016). Quantifying the Spillovers from China Rebalancing Using a Multi-Sector Ricardian Trade Model. IMF Working Paper WP/16/219. International Monetary Fund.

Mattoo, A., Mishra, P., \& Subramanian, A. (2016). Beggar-thy-Neighbor Effects of Exchange Rates? A Study of the Renminbi. American Economic Journal: Economic Policy, 9(4), 344-66.

Melitz, J. M., \& Redding, S. J. (2014). Heterogeneous Firms and Trade. Handbook of International Economics, 4, 1-54.

Melitz, M. J. (2003). The Impact of Trade on Intra-Industry Reallocations and Aggregate Industry Productivity. Econometrica, 71(6), 1695-1725.

Moreira, M. M. (2007). Fear of China: is there a future for manufacturing in Latin America? World Development, 35, 355-376.

Mowatt, R. (2017). Trade policy issues in Latin America and the Caribbean: views from country authorities and current state of play. Background Papers. Washington, D.C.: International Monetary Fund.

Ravikumar, B., Santacreu, A. M., \& Sposi, M. J. (2019). Capital Accumulation and Dynamic Gains from Trade. Working Paper, Federal Reserve Bank of St. Louis.

Reyes-Heroles, R. (2016). The Role of Trade Costs in the Surge of Trade Imbalances. mimeo.

UNCTAD. (2013). Non-Tariff Measures to Trade: Economic and Policy Issues for Developing Countries. New York and Geneva: United Nations.

World Bank. (2016). Global Economic Prospects. Washington, DC. 


\section{APPENDIX I: CALIBRATION OF THE SHOCKS USING BRAZIL AS BENCHMARK}

The same exercise was done using Brazil — another emerging economy — as a benchmark, and the results are not significantly different from those using the U.S. as benchmark. Figure I.1 shows the change in real GDP in all countries in the world following the combined shock, using both the U.S. (panel A) and Brazil (panel B) as benchmarks. The results are not substantially different. Regardless of the benchmark used, most countries in LAC get hurt as a result of China's rebalancing, with the exception of Mexico, Venezuela, Ecuador, and Central American countries, which report small increases in their real GDP, relative to the situation of no rebalancing.

Figure I.1. Effect of China's rebalancing on the World's Real GDP

Panel A. Using U.S. as benchmark

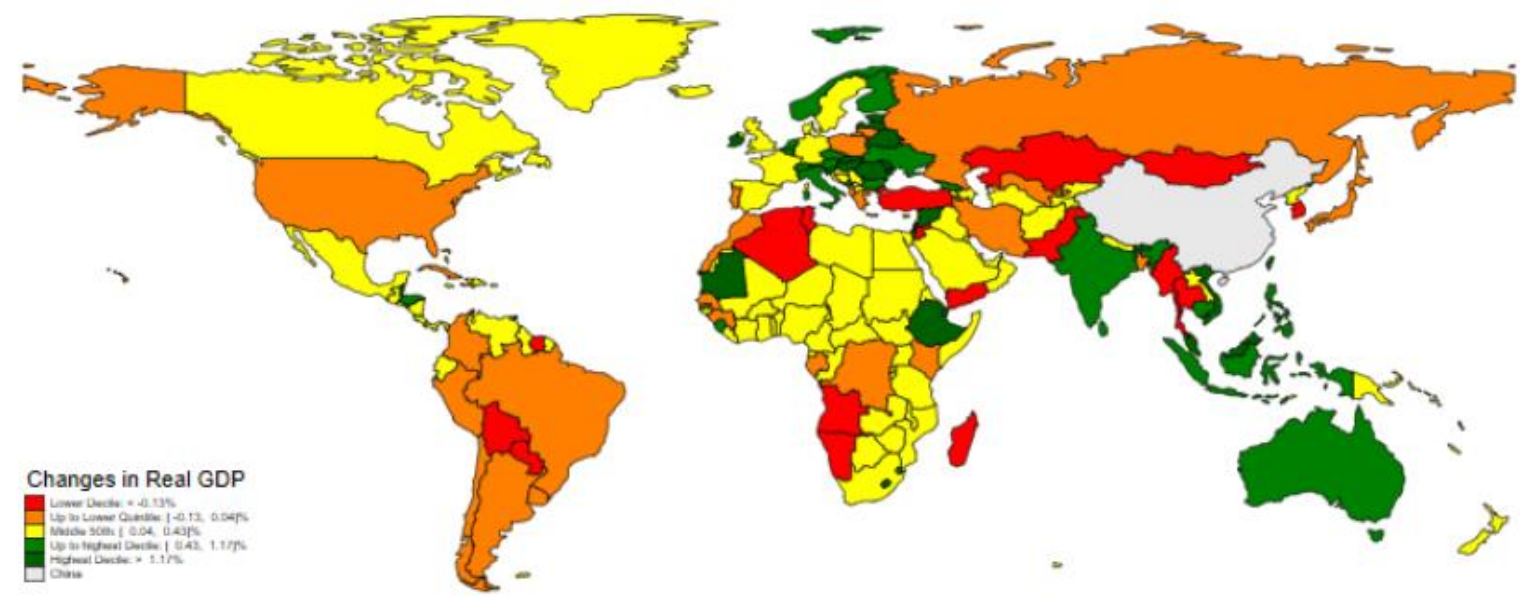

Panel B. Using Brazil as benchmark

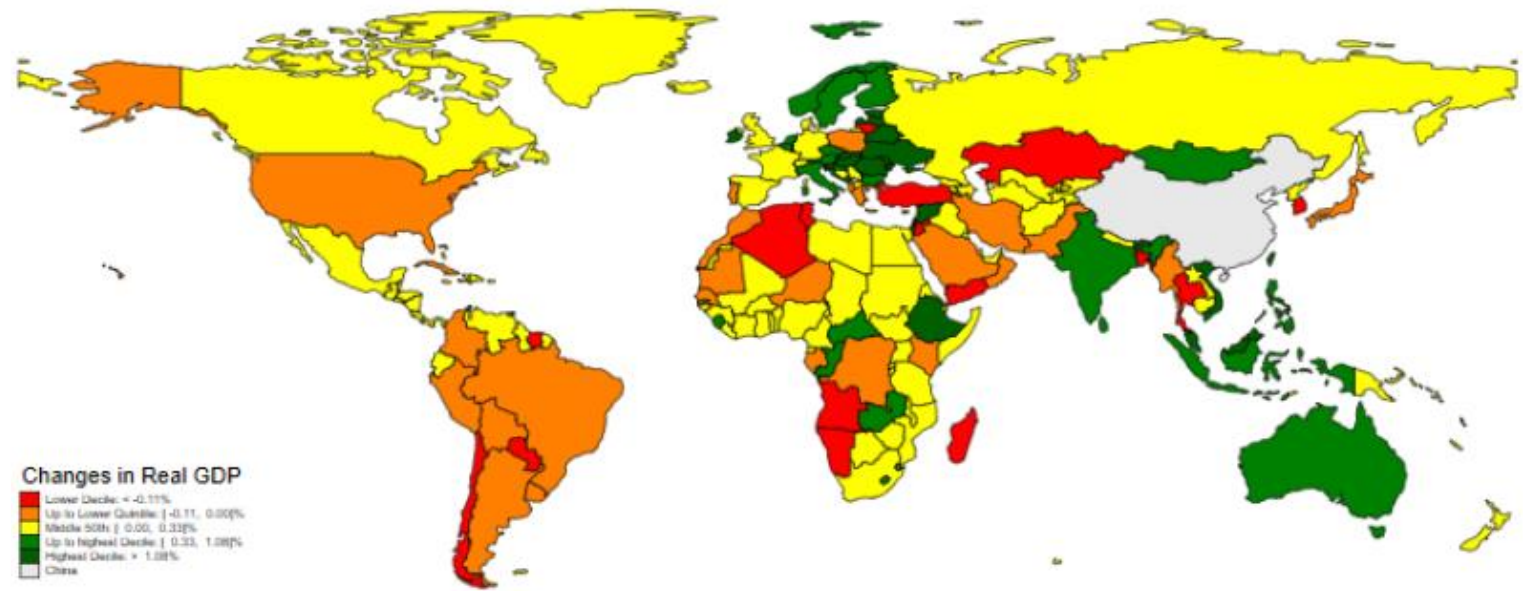

Source: IMF staff calculations. 


\section{APPENDIX II: LAC'S COMPETITIVE LANDSCAPE}

Table II.1. Top Exports of LA6 Countries

(To determine competitors)

\begin{tabular}{|c|c|}
\hline Argentina & 50.6 \\
\hline Soya oil cake & 16.5 \\
\hline Soya beans & 7.4 \\
\hline Soya-bean oil and its fractions & 6.8 \\
\hline Maize (corn) & 5.7 \\
\hline Vehicles (transport of goods) & 5.2 \\
\hline Gold (unwrought, semi-manufactured, powder) & 3.9 \\
\hline Motor vehicles (transport of persons) & 3.4 \\
\hline Wheat and meslin & 1.8 \\
\hline Brazil & 49.7 \\
\hline Soya beans & 10.8 \\
\hline Iron ores and concentrates & 7.9 \\
\hline Petroleum oils (crude) & 6.0 \\
\hline Cane or beet sugar (solid) & 3.9 \\
\hline Meat and edible offal of poultry & 3.3 \\
\hline Chemical wood pulp, soda or sulphate & 3.0 \\
\hline Soya oil cake & 3.0 \\
\hline Coffee & 3.0 \\
\hline Maize (corn) & 2.6 \\
\hline Aircraft, spacecraft & 2.3 \\
\hline Meat of bovine animals (frozen) & 2.0 \\
\hline Motor vehicles (transport of persons) & 1.8 \\
\hline Chile & 50.6 \\
\hline Copper (refined, copper alloys) & 22.7 \\
\hline Copper ores and concentrates & 20.2 \\
\hline Chemical wood pulp, soda or sulphate & 4.1 \\
\hline Copper (unrefined, copper anodes) & 3.6 \\
\hline Colombia & 48.0 \\
\hline Petroleum oils (crude) & 33.8 \\
\hline Coal & 14.3 \\
\hline Mexico & 50.3 \\
\hline Motor vehicles (transport of persons) & 8.8 \\
\hline Motor vehicles (parts and accessories) & 6.5 \\
\hline Vehicles (transport of goods) & 5.9 \\
\hline Automatic data processing machines & 5.3 \\
\hline Petroleum oils (crude) & 5.0 \\
\hline Line telephony or line telegraphy apparatus & 4.0 \\
\hline Television receivers & 3.8 \\
\hline Insulated wire/cable/electric conductors & 3.0 \\
\hline Tractors & 2.4 \\
\hline Instruments/appliances used in medical, surgical, dental or veterinary sciences & 2.1 \\
\hline Seats & 2.1 \\
\hline Refrigerators, freezers & 1.3 \\
\hline Peru & 48.4 \\
\hline Copper ores and concentrates & 19.1 \\
\hline Gold (unwrought, semi-manufactured, powder) & 16.4 \\
\hline Petroleum oils (not crude) & 4.8 \\
\hline Copper (refined, copper alloys) & 4.5 \\
\hline Flours, meal and pellets of fish/aquatic invertebrates & 3.6 \\
\hline
\end{tabular}

Source: BACI World Trade Database and IMF staff calculations. 
Table II.2. Competitors for LA6 Exports

\begin{tabular}{|c|c|c|c|c|}
\hline \multicolumn{5}{|c|}{ Argentina } \\
\hline Australia & France & Malaysia & Serbia & United Arab Emirates \\
\hline Belgium-Luxembourg & Germany & Mexico & India & Turkey \\
\hline Bolivia & Hong Kong SAR & Netherlands & Singapore & Ukraine \\
\hline Brazil & Hungary & Paraguay & SACU & United Kingdom \\
\hline Bulgaria & Italy & Poland & Spain & USA \\
\hline Canada & Japan & Romania & Switzerland & Uruguay \\
\hline China & Rep. of Korea & Russia & Thailand & \\
\hline \multicolumn{5}{|c|}{ Brazil } \\
\hline Angola & Finland & Italy & Poland & Switzerland \\
\hline Argentina & France & Japan & Portugal & Thailand \\
\hline Australia & Germany & Rep. of Korea & Romania & United Arab Emirates \\
\hline Belgium-Luxembourg & Guatemala & Kuwait & Russia & Ukraine \\
\hline Bolivia & Honduras & Mexico & Saudi Arabia & United Kingdom \\
\hline Canada & Hong Kong SAR & Oman & Serbia & USA \\
\hline Chile & Hungary & Netherlands & India & Uruguay \\
\hline China & Indonesia & New Zealand & Vietnam & Venezuela \\
\hline Colombia & Iran & Nigeria & SACU & \\
\hline Cuba & Iraq & Norway & Spain & \\
\hline Ethiopia & Ireland & Paraguay & Sweden & \\
\hline \multicolumn{5}{|c|}{ Chile } \\
\hline Australia & Dem. Rep. of Congo & Rep. of Korea & Poland & Spain \\
\hline Armenia & Finland & Mexico & Portugal & Sweden \\
\hline Belgium-Luxembourg & Germany & Mongolia & Russia & USA \\
\hline Brazil & Indonesia & Pakistan & India & Uruguay \\
\hline Bulgaria & Japan & Peru & Slovakia & Zambia \\
\hline Canada & Kazakhstan & Philippines & SACU & \\
\hline \multicolumn{5}{|c|}{ Colombia } \\
\hline Angola & Indonesia & Mongolia & Russia & USA \\
\hline Australia & Iraq & Nigeria & Saudi Arabia & Venezuela \\
\hline Canada & Dem. P. Rep. of Korea & Norway & SACU & \\
\hline China & Kuwait & Poland & United Arab Emirates & \\
\hline \multicolumn{5}{|c|}{ Mexico } \\
\hline Angola & Hong Kong SAR & Malaysia & Romania & Switzerland \\
\hline Austria & Hungary & Other Asia & Russia & Thailand \\
\hline Belgium-Luxembourg & Iraq & Morocco & Saudi Arabia & United Arab Emirates \\
\hline Canada & Ireland & Netherlands & Singapore & Turkey \\
\hline China & Italy & Nigeria & Slovakia & United Kingdom \\
\hline Czech Rep. & Japan & Norway & Vietnam & USA \\
\hline France & Rep. of Korea & Philippines & Spain & Venezuela \\
\hline Germany & Kuwait & Poland & Sweden & \\
\hline \multicolumn{5}{|c|}{ Peru } \\
\hline Australia & Germany & Malaysia & Russia & Switzerland \\
\hline Belgium-Luxembourg & Hong Kong SAR & Mexico & Saudi Arabia & Thailand \\
\hline Brazil & Iceland & Mongolia & India & United Arab Emirates \\
\hline Canada & Indonesia & Morocco & Singapore & Turkey \\
\hline Chile & Japan & Netherlands & Vietnam & United Kingdom \\
\hline Dem. Rep. of Congo & Kazakhstan & Philippines & SACU & USA \\
\hline Denmark & Rep. of Korea & Poland & Spain & Zambia \\
\hline
\end{tabular}

Source: BACI World Trade Database and IMF staff calculations. 


\section{Figure II.1.LA6: Top 10 Competitors in 2015, based on CBI}

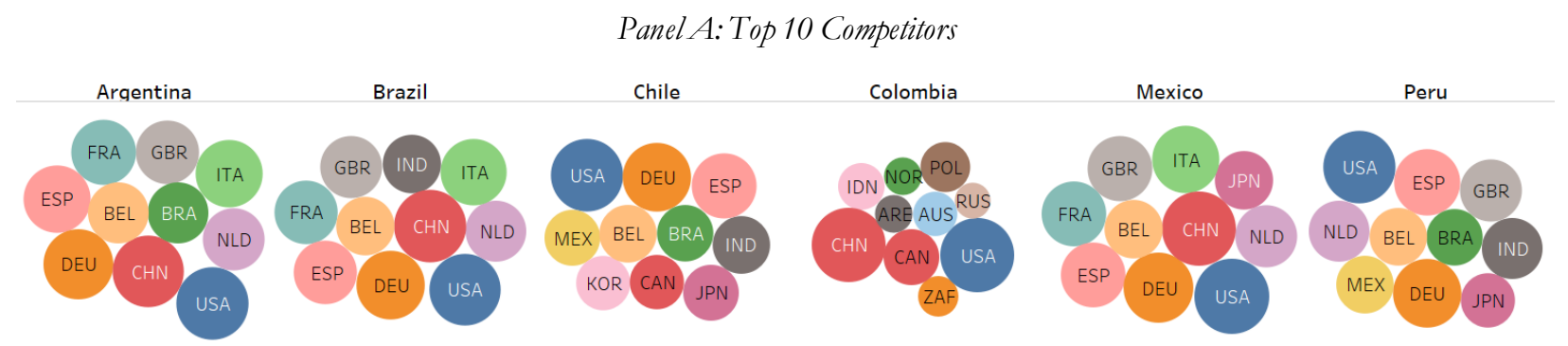

Panel B: Top 10 Competitors Among Advanced Economies

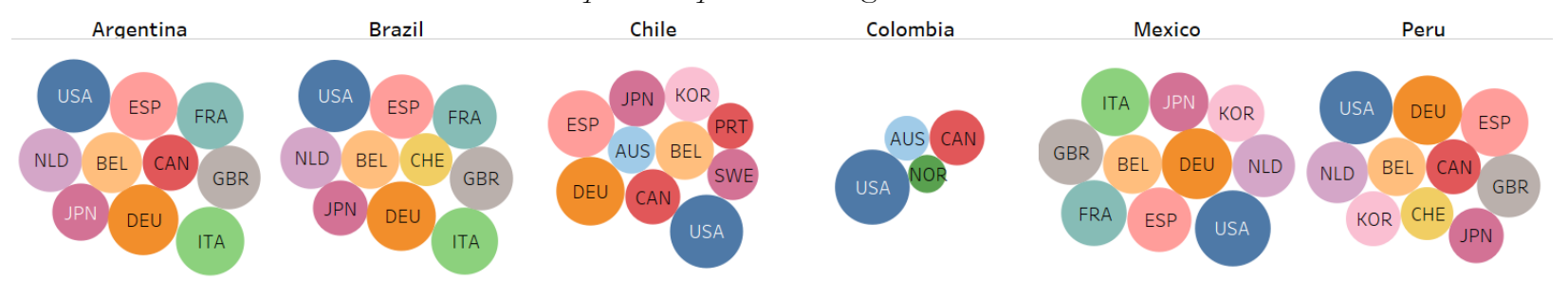

Panel C: Top 10 Competitors Among Emerging and Developing Economies
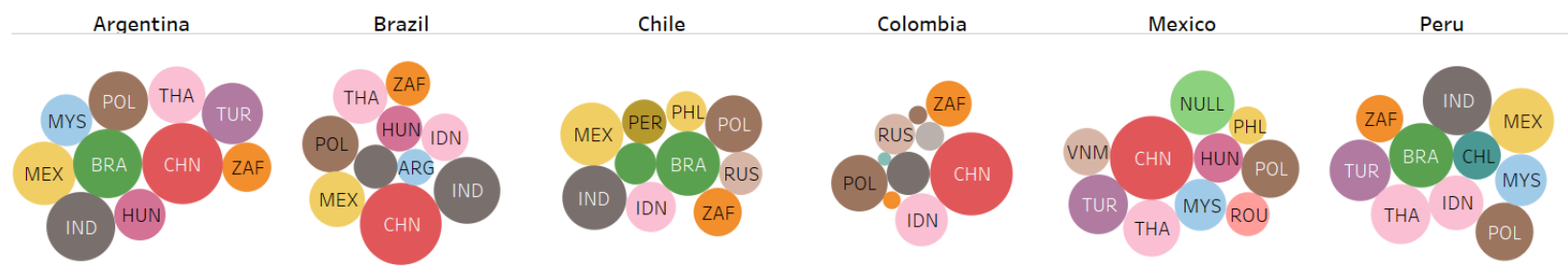

Source: HS-6 level data from BACI World Trade Da tabase and IMF staff calculations. 


\section{Figure II.2. LA6: Competition over time, based on CBI}

Panel A: Top 10 Competitors in 2000
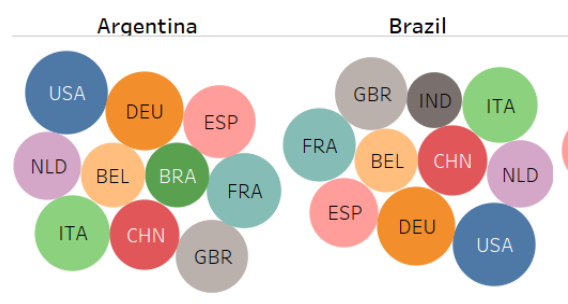

Chile

Colombia

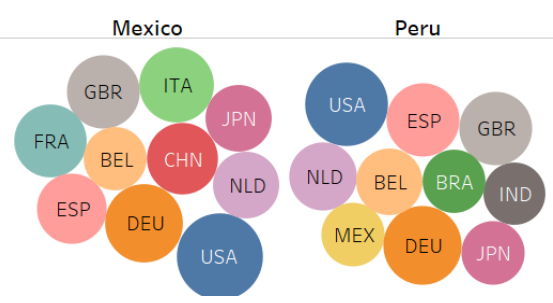

Panel B: Top 10 Competitors in 2015
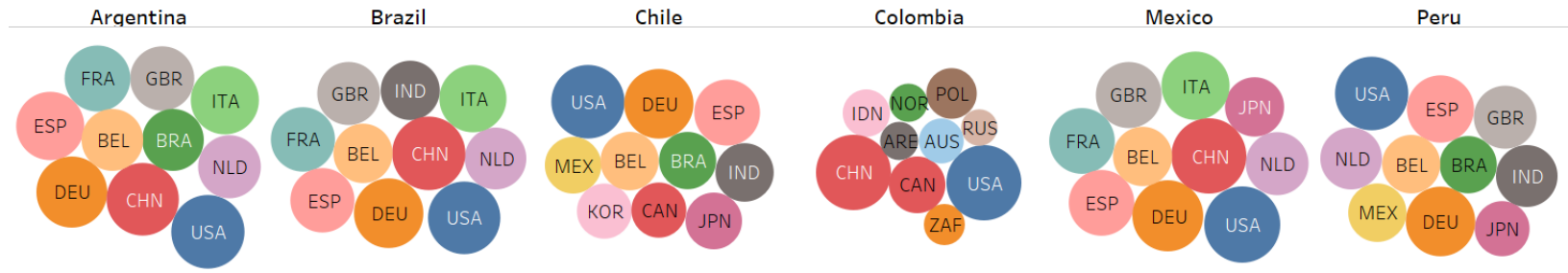

Source: HS-6 level data from BACI World Trade Da tabase and IMF staff calculations. 
Figure II.3. LA6: Competition over time, based on CBI
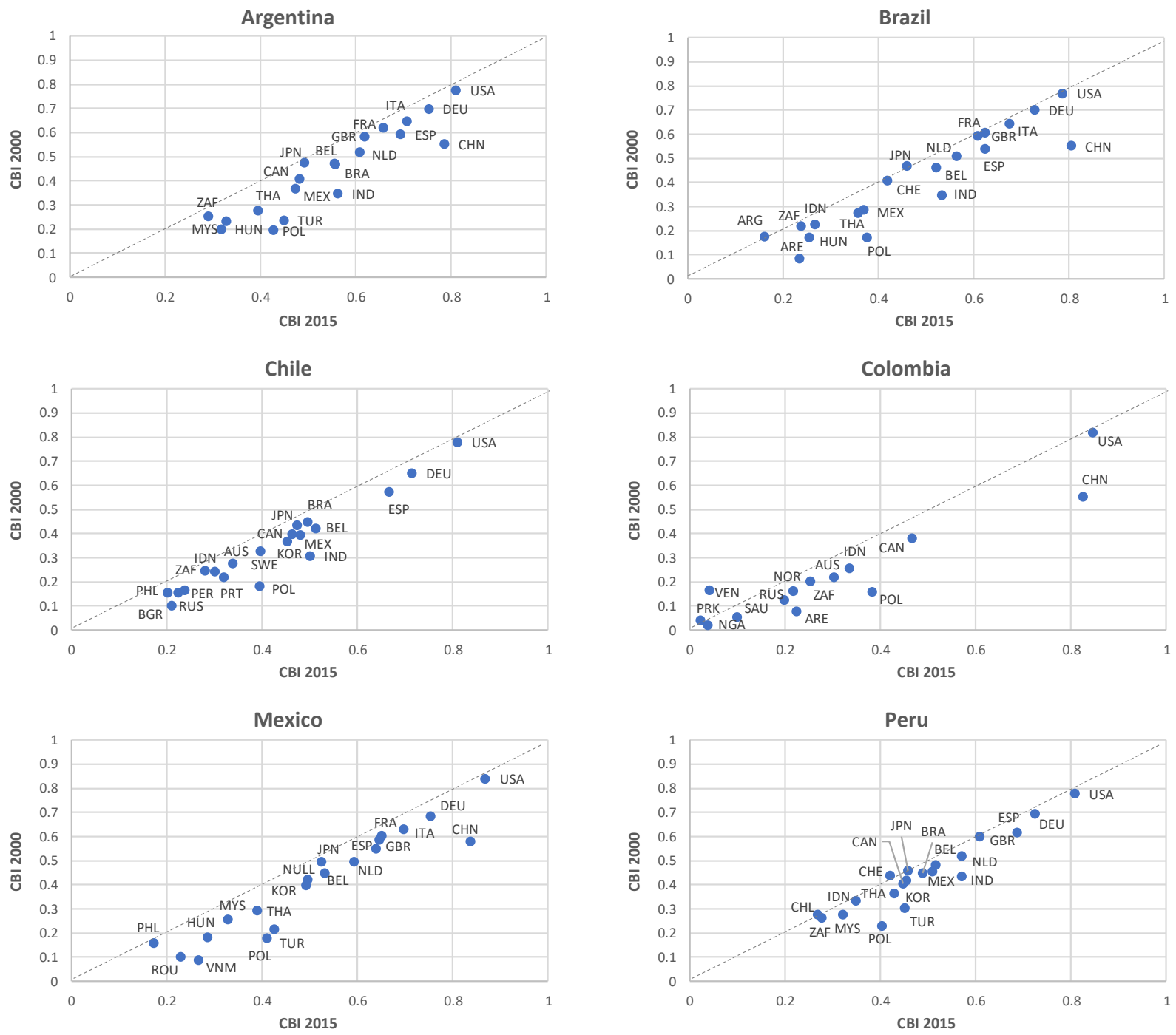

Source: HS-6 level data from BACI World Trade Da tabase and IMF staff calculations.

Note: The dotted line represents the 45-degree line. For a given LA6 country, if a competitor is loca ted below the 45degree line it means that competition has increased between 2000 and 2015. 
Figure II.4. LA6: Competition in Top 10 Product Lines, based on CBI
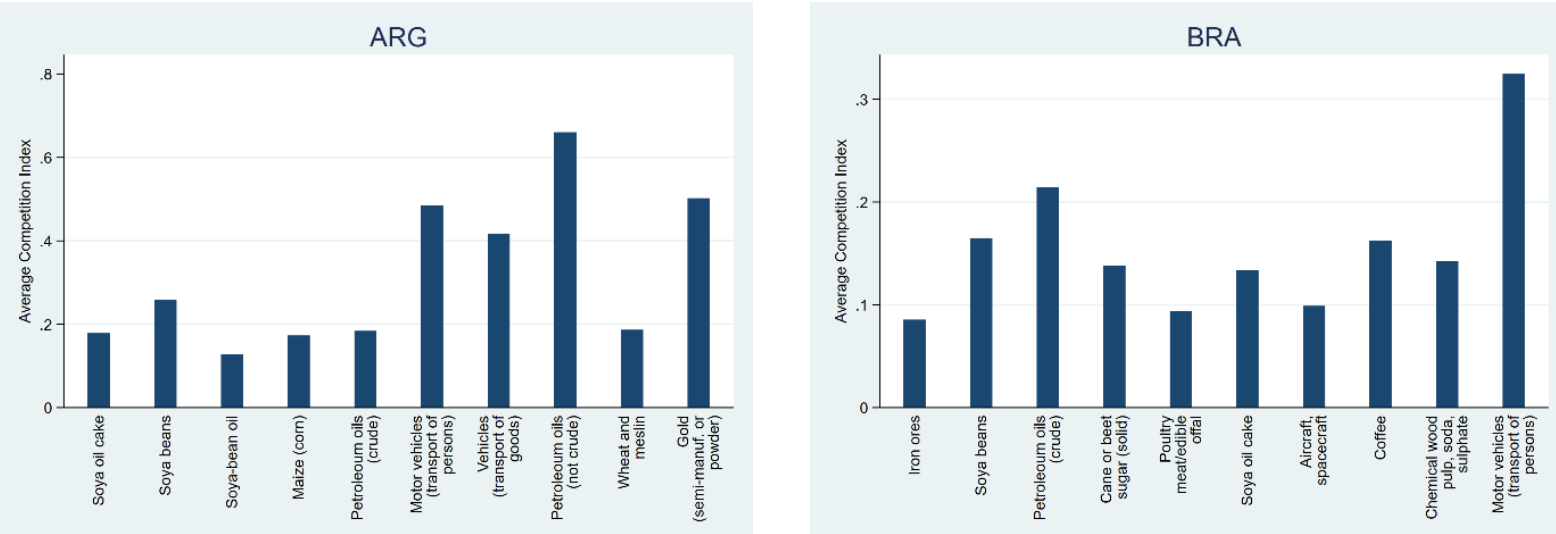

$\mathrm{CHL}$

$\mathrm{COL}$
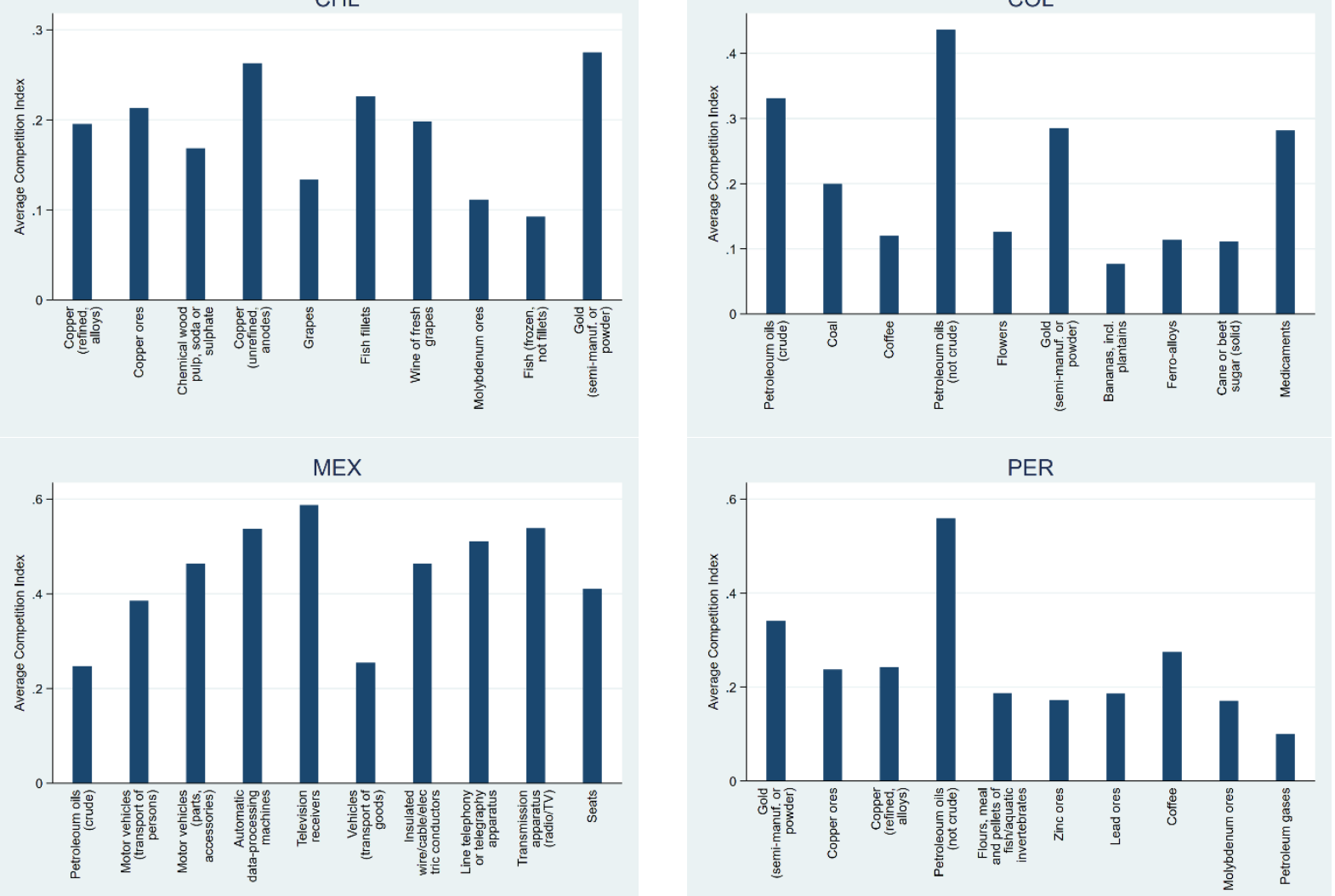

Source: HS-6 level data from BACI World Trade Da tabase and IMF staff calculations. 


\section{APPENDIX III: SEPARATING DEMAND AND PRODUCTION SHOCKS}

Figure III.1. shows that the absolute impacts are very close for the combined shock and the one where only the preference shock is considered. This implies that the preference shock is by far the most significant.

\section{Figure III.1. Effect of China's rebalancing on the World's Real GDP}

Panel A. Full effect considering Demand and Production Adjustments

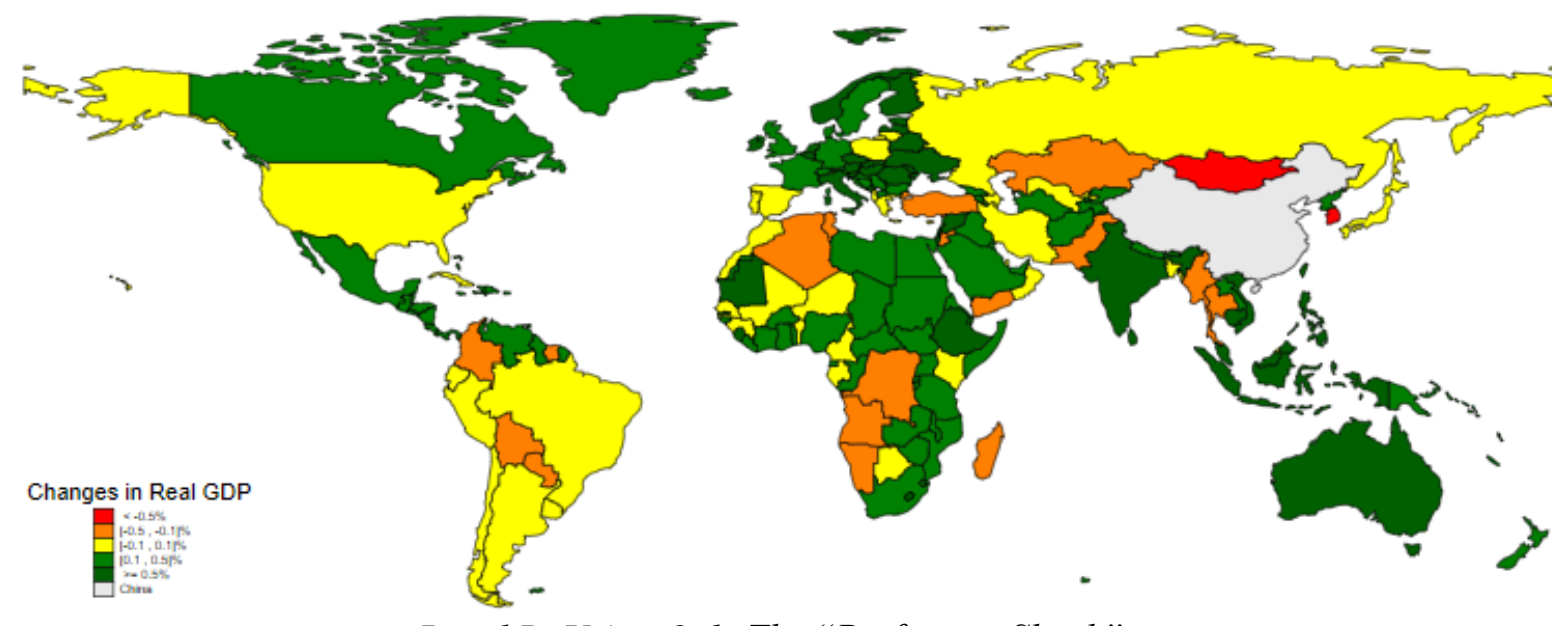

Panel B. Using Only The "Preference Shock"

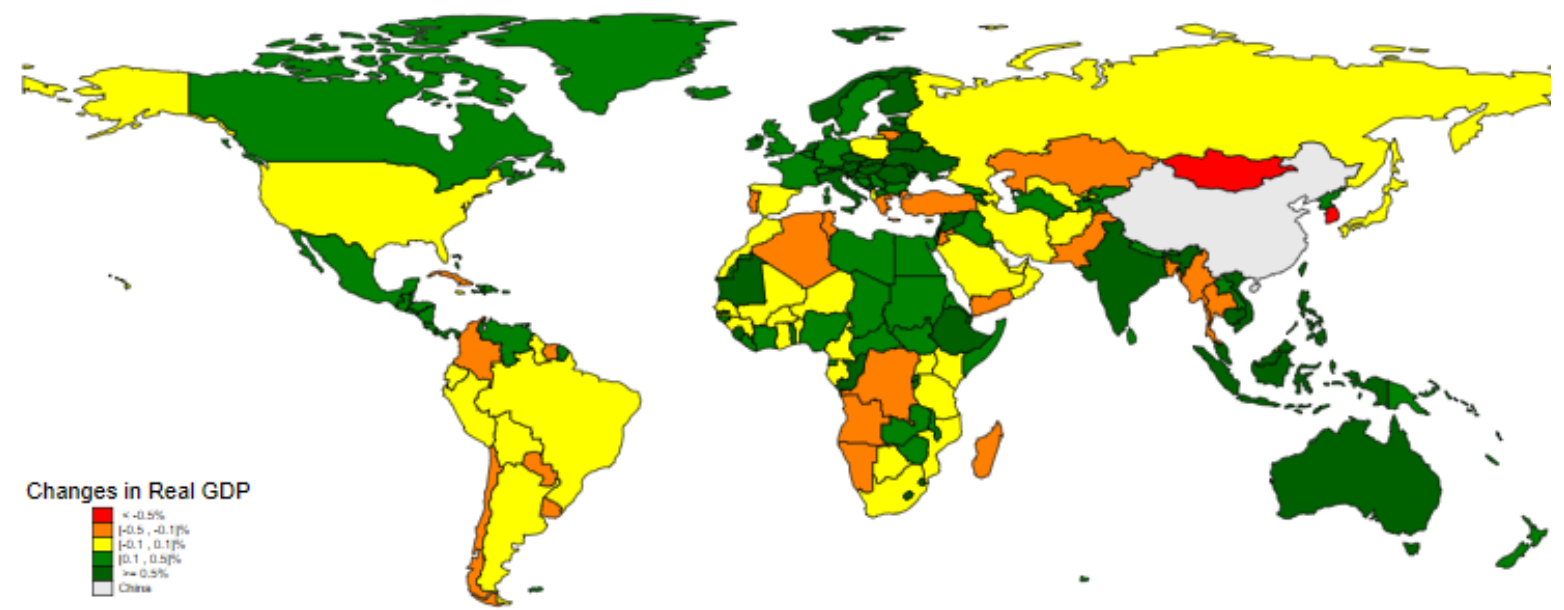

Source: IMF staff calculations. 